\title{
FRAUD IN THE NEW-ISSUES MARKET: \\ EMPIRICAL EVIDENCE ON SECURITIES CLASS ACTIONS
}

JAMES BOHN† \& STEPHEN ChOI††

\section{TABLE OF CONTENTS}

INTRODUCTION ...................... 903

I. THE ENFORCEMENT VERSUS THE STRIKE-SUIT

THEORIES . . . . . . . . . . . . . . . . . . 912

A. The Strike-Suit Theory . . . . . . . . . . . . 918

B. The Enforcement Theory . . . . . . . . . . . . . . . 924

II. SAMPLE SELECTION METHODOLOGY AND DATA

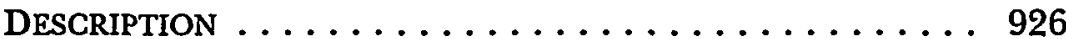

A. Summary Statistics . . . . . . . . . . . . . . 928

1. IPO and Suit Incidence . . . . . . . . . . . . . 929

2. Resolution Time Period and Suit

Disposition ................... 930

3. Offering Amount .............. 935

4. Aftermarket Losses . . . . . . . . . . . . . 937

5. Standard Industry Classification Code . . . . . . . 940

B. Implications . . . . . . . . . . . . . . . 944

1. Low Frequency of IPO Suits . . . . . . . . . . 944

2. Plaintiffs' Attorneys' Incentives . . . . . . . . . 945

3. SEC Enforcement . . . . . . . . . . . . . 947

III. EMPIRICAL TESTS OF THE ENFORCEMENT VERSUS

THE STRIKE-SUIT THEORIES . . . . . . . . . . . . . . . . 949

A. The Decision to File Suit . . . . . . . . . . . . . . 950

B. Ex Ante Proxies for Merit ............... 958

1. Insider Sell-Off During an IPO . . . . . . . . 960

2. Corporate Governance Structure ... . . . . . 962

C. The Settlement Process . . . . . . . . . . . . 970

D. Event Study of Returns at Time of Suit

Filing ................... 977

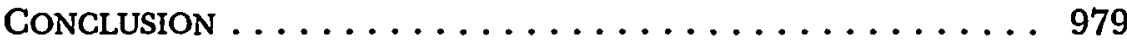

† Business Economics Ph.D. Candidate, Harvard University.

t† Visiting Assistant Professor of Law, University of Chicago. We would like to thank Douglas Baird, Lucian Bebchuk, Richard Craswell, Jeffrey Gordon, Robert Helman, Louis Kaplow, Laura Lin, Un Kyung Park, Mark Ramseyer, Jay Ritter, Roberta Romano, Kent Smetters, and the participants of the Harvard Law School Law \& Economics Research Seminar and the University of Chicago Law School Law \& Economics Seminar for their helpful comments. 


\section{INTRODUCTION}

On Friday morning, April 2, 1993, Philip Morris announced its plans to slash the average price of its Marlboro line of cigarettes by forty cents per pack. ${ }^{1}$ Philip Morris also reported that the price cut would reduce projected earnings of its tobacco products for 1993 by nearly forty percent relative to the previous year. ${ }^{2}$ The stock market responded quickly to the events of this day, later labelled "Marlboro Friday": Philip Morris's common stock lost nearly twenty-five percent of its value, plummeting from $\$ 64.125$ per share at the close of trading on April 1 to $\$ 49.375$ per share by the close of trading on April 2. Less than five hours after Philip Morris's announcement, plaintiffs filed the first of ten class-action lawsuits alleging fraud violations under section 10(b) of the Securities Exchange Act of 1934 and Rule 10b-5 with respect to the Marlboro brand. ${ }^{3}$ Each separate class action claimed that Philip Morris had used fraudulent statements to augment the price of Philip Morris's common stock. ${ }^{4}$ Among the plaintiffs' attorneys firms leading the several class actions was Milberg, Weiss, Bershad, Hynes \& Lerach, $^{5}$ which prior to the Philip Morris suit had earned millions through settlements of other suits against newly public firms whose securities had performed poorly in aftermarket trading. ${ }^{6}$ Unlike the vast majority of securities litigation, however, the class actions against Philip Morris did not end in settlement. ${ }^{7}$ Rather, almost two years later, the U.S. District Court for the Southern District of New York

${ }^{1}$ Marlboro cigarettes are the most popular cigarettes sold in the United States, and sales of full-priced brands of cigarettes such as Marlboro constitute nearly $90 \%$ of the profits for Philip Morris's tobacco operations. See In re Philip Morris Sec. Litig., 872 F. Supp. 97, 99 (S.D.N.Y. 1995).

${ }^{2}$ See id.

${ }^{3}$ Four more suits were filed that same day. The remaining five suits were filed the following business day, Monday, April 5, 1993. See id. at 98.

${ }^{4}$ See id.

${ }^{3}$ Other plaintiffs' attorneys law firms filing suit included Abbey \& Ellis and Barrack, Rodos \& Bacine. See Junda Woo, Judges Show Growing Skepticism in ClassAction Securities Cases, WALL ST. J., Jan. 11, 1995, at B8.

6 "Aftermarket" refers to the secondary securities market. For example, trades between investors on the New York Stock Exchange and on NASDAQ are part of the aftermarket. This is distinguished from the primary market which involves the offering of securities from companies directly to investors. In 1994 alone, Milberg, Weiss was among the principal law firms in cases that eventually settled for $\$ 295$ million. See Jill Abramson \& Amy Stevens, Class-Action Clash: King of "Strike Suits" Finds Style Cramped By Legal-Overhaul Bill, WALL ST. J., Mar. 30, 1995, at A1.

${ }^{7}$ Over $90 \%$ of securities class actions eventually end in settlement. See infra part II.A.2 (reporting the disposition of suits in an IPO sample). 
dismissed the case, finding no evidence of fraud on Philip Morris's part. ${ }^{8}$ In its decision, the court pointed out that Milberg, Weiss's initial complaint alleged that Philip Morris-a cigarette companyhad engaged in conduct "to create and prolong the illusion of [Philip Morris'] success in the toy industry." More importantly, the short time span between Philip Morris's Marlboro Friday announcement and the first class-action filing-less than five hours-led the district court to question the diligence of the plaintiffs' attorneys in investigating the presence of actual fraud on Philip Morris's part. ${ }^{10}$ Rather than turning on the presence of any fraud, Milberg, Weiss's case seemed to depend primarily on the size of Philip Morris's common stock price decline.

The Philip Morris case illustrates a much-debated phenomenon in the securities industry: the frivolous lawsuit. ${ }^{11}$ Opportunistic plaintiffs' attorneys continuously monitor securities prices, probing for recent offerings that perform poorly in the aftermarket. Once a security's price suffers a decline sufficient to generate a potential damages award large enough to cover the expected costs of litigation, plaintiffs' attorneys bring suit, hoping for a swift settlement. Defendants of such suits-including the issuer, directors and officers of the issuer, auditors, attorneys, and underwriters-almost always settle. Several factors compel settlement, including: the risk aversion of the directors and officers, the existence of directors and officers' insurance, and the desire of the issuer and underwriters to minimize negative publicity and to mitigate the costs of defending against a prolonged frivolous suit. ${ }^{12}$

${ }^{8}$ See In re Philip Morris Sec. Litig., 872 F. Supp. 97, 103 (S.D.N.Y. 1995).

${ }^{9} \mathrm{Id}$. at 98 (alteration in original) (quoting plaintiffs' complaint).

${ }^{10}$ See id. In data presented to the Senate Securities Subcommittee, Melvyn I. Weiss indicated that of the 229 securities class actions that Milberg, Weiss filed from 1990 to 1993, 157 were filed within 10 days of the information disclosures upon which the plaintiffs' claims were based. See Private Litigation Under the Federal Securities Laws: Hearings Before the Subcomm. on Securities of the Senate Comm. on Banking, Housing, and Urban Affairs, 103d Cong., 1st Sess. 141, 465-70, 472-502, 53846 (1993) (letter from Melvyn I. Weiss to Sen. Donald W. Riegle, Jr., Chairman, Senate Comm. on Banking, Housing, and Urban Affairs).

"For another example, see Hershfang v. Citicorp, 767 F. Supp. 1251, 1258 (S.D.N.Y. 1991) (criticizing the plaintiffs' attorneys for filing a complaint made up primarily of newspaper clippings without any specific facts relating to the culpability of the defendants).

${ }^{12}$ See Janet C. Alexander, Do the Merits Matter? A Study of Settlements in Securities Class Actions, 43 STAN. L. REv. 497, $529-57$ (1991) (observing that the desire of corporate directors and officers to settle class-action lawsuits is matched by an eagerness among plaintiffs' lawyers to collect their contingency fees through 
Recently, Congress responded to the problem of frivolous securities-fraud suits by enacting the Private Securities Litigation Reform Act of $1995^{13}$ (Reform Act) over President Clinton's veto. ${ }^{14}$ Through the Reform Act, Congress attempted to curtail the ability of plaintiffs' attorneys to rely upon professional plaintiffs' class representatives and to increase the ability of institutional investors to take control of securities-fraud class actions. ${ }^{15}$ In addition, class-action complaints must now plead the alleged fraud with particularity, and courts are required to review such complaints for violation of Federal Rule of Civil Procedure 11. ${ }^{16}$ Soft information projections are also given greater protection through an expanded safe harbor provision under the Reform Act. ${ }^{17} \mathrm{~A}$ question remains, however, as to the general nature of securities class actions. As the Philip Morris case demonstrates, some frivolous securities class actions do occur. But do frivolous suits predominate? Is there any evidence of merit-based enforcement actions?

Many scholars view class-action suits with a mixture of approbation and skepticism. Some perceive class actions as playing an enforcement role and contend that class actions serve as an

settlement).

${ }^{13}$ Pub. L. No. 104-67, 109 Stat. 737 (to be codified at scattered sections of 15 U.S.C.) (amending the Securities Act and the Exchange Act).

${ }^{14}$ See Several experts have commented on the impact of reform. See, e.g., John C. Coffee, Jr., Securities Litigation Reform: An Agenda for the Senate, N.Y. L.J., Mar. 23, 1995, at 5 (explaining the probable impact of such reforms as "loser pays" and the abolition of the "fraud on the market" theory); William S. Lerach, Prevalence and Economic Impact of Securities Class Actions: Is Reform Necessary?, in AVOIDINC AND MANAGING SECURITIES LITIGATION AND SEC ENFORCEMENT INQUIRIES FOR IN-HOUSE Counsel 1995, at 7, 10, 13-23 (PLI Corp. Practice Course Handbook Series No. B888,1995 ) (arguing that these proposals "would cripple private enforcement of the anti-fraud provisions of the Securities Exchange Act of 1934, weaken the integrity of our nation's securities markets, damage investors and ultimately undermine capital formation, which depends upon honest markets").

${ }^{15}$ See Private Securities Litigation Reform Act of 1995, sec. 101, 109 Stat. at 73849 (to be codified at Securities Act $\$ 27,15$ U.S.C. $\$ 77 z-1$, and Securities Exchange Act § 21D, 15 U.S.C. § 78u-4).

${ }_{16}$ See sec. 101(a), 109 Stat. at 737-38 (to be codified at Securities Act $\$ 27($ a)(2), 15 U.S.C. 77z-1(a)(2)); sec. 101(b), 109 Stat. at 743 (to be codified at Securities Exchange Act § $21 \mathrm{D}(\mathrm{a})(2), 15$ U.S.C. § 78u-4(a)(2)); see also FED. R. CIv. P. 11 (enumerating circumstances under which a court may and must impose sanctions on an attorney).

${ }^{17}$ See sec. 102(a), 109 Stat. at 749-52 (to be codified at Securities Act $\$ 27 A, 15$ U.S.C. $\$ 77 z-2$ ); sec. 102(b), 109 Stat. at 753-56 (to be codified at Securities Exchange Act $\$ 21 E, 15$ U.S.C. $\$ 78 u-5$ ). Due to the relatively recent enactment of the Reform Act, this Article does not deal specifically with any of its provisions. 
important check on management and ensure the adequacy of corporate disclosure. ${ }^{18}$ Under this enforcement theory, shareholder litigation complements the SEC's own policing activities, ${ }^{19}$ providing plaintiffs and plaintiffs' attorneys with an incentive to ferret out misleading disclosures and safeguard the integrity of financial markets. Detractors of the recent Reform Act, for example, contend strenuously that the majority of suits are indeed merit based and that restricting securities-fraud suits exposes unsuspecting shareholders to the sharp practices of misleading issuers. ${ }^{20}$ Others, however, view the class action as a mechanism for plaintiffs' attorneys to extract rents from the corporate treasuries of defendant firms and insurance companies. ${ }^{21}$ They argue that

${ }^{18}$ See, e.g., William S. Lerach, Securities Class Actions and Derivative Litigations Involving Public Companies: A Plaintiff's Perspective, in 1 SECURITIES LITIGATION 7, $13-$ 18 (Bruce G. Vanyo \& Edward J. Yodowitz eds., 1985) (suggesting that private securities litigation is necessary to curb corporate excesses that would otherwise pass unchallenged by overburdened regulatory agencies); Joel Seligman, The Merits Do Matter: A Comment on Professor Grundfest's 'Disimplying Private Rights of Action Under the Federal Securities Laws: The Commission's Authority", 108 HARV. L. REV. 438, 439-57 (1994) (arguing that Professor Grundfest has failed to establish adequately the need for new legislative restrictions on federal securities litigation); see also Barbara A. Banoff \& Benjamin S. Duval, Jr., The Class Action As a Mechanism for Enforcing the Federal Securities Laws: An Empirical Study of the Burdens Imposed, 31 WAYNE L. REV. 1, 32 ("Proponents say that class actions promote judicial economy, compensate the victims of wrongdoing, prevent unjust enrichment, and deter future misconduct."); Jonathan R. Macey \& Geoffrey P. Miller, The Plaintiffs' Attorney's Role in Class Action and Derivative Litigation: Economic Analysis and Recommendations for Reform, $58 \mathrm{U}$. CHI. L. REV. 1, 8-9 (1991) (describing economic justifications for class-action suits); David Rosenberg, Class Actions for Mass Torts: Doing Individual Justice By Collective Means, 62 IND. L.J. 561, 562 (1987) (arguing that class actions in the context of mass torts promote collective benefits of process efficiency, outcome consistency, and welfare maximization).

${ }^{19}$ Both the Securities Act of 1933, 15 U.S.C. $\$ \S 77 a-77 a a$ (1994), and the Securities Exchange Act of 1934, 15 U.S.C. $\$ \S 78 \mathrm{a}-781 l$ (1994), empower the SEC to enforce the SEC's rules and regulations. Section 20(a) of the Securities Act gives the SEC the power to conduct investigations into possible Securities Act violations. See 15 U.S.C. $\$ 77 \mathrm{~s}$. Under $\$ 20(\mathrm{~b})$ of the Securities Act, the SEC may seek injunctive relief from the federal courts for actual or imminent violations. See 15 U.S.C. $\S 77 \mathrm{t}$. Section 21(a) of the Exchange Act empowers the SEC to conduct investigations into possible Exchange Act violations. See 15 U.S.C. \$ 78u(a). Under \$ 21(d) of the Exchange Act, the SEC may seek injunctive relief for actual or imminent violations. See 15 U.S.C. $\$ 78 \mathrm{u}(\mathrm{d})$.

${ }^{20}$ See Lerach, supra note 14, at 18-22, 31, 32.

${ }^{21}$ See Alexander, supra note 12, at 570-77; John C. Coffee, Jr., Rethinking the Class Action: A Policy Primer on Reform, 62 IND. L.J. 625, 638-39 (1987) [hereinafter Coffee, Rethinking the Class Action]; John C. Coffee, Jr., The Unfaithful Champion: The Plaintiff As Monitor in Shareholder Litigation, LAW \& CONTEMP. PROBS., Summer 1985, at 5, 9 [hereinafter Coffee, The Unfaithful Champion]; see also Sylvia R. Lazos, Note, Abuse in Plaintiff Class Action Settlements: The Need for a Guardian During Pretrial Settlement 
the overwhelming desire of defendants to avoid trial inevitably results in strike suits seeking a favorable settlement.

Whether securities-fraud suits are merit based or strike-suit based assumes a particular significance in the new-issues market. The cost of strike suits is especially burdensome for companies going public for the first time. Although larger, more established companies may enjoy alternative sources of funding, new growth companies often must resort to the public equity markets. ${ }^{22}$ Furthermore, new-growth companies often have volatile stock prices and lack a disclosure track record, making them particularly vulnerable to strike suits. On the other hand, the danger to investors is also especially acute during initial public offerings (IPOs). Much uncertainty surrounds the issuance of a private company's equity. ${ }^{23}$ Investors generally possess only limited information on the value of an IPO; the issuing firm's managers themselves may have only rough estimates of an IPO's fundamental value. ${ }^{24}$ As a result, agency problems exist at the time a firm goes public: ${ }^{25}$ owners of the firm have an incentive to inflate the prospects of the firm to ensure the success of the IPO. In addition, insiders seeking to sell part of their holdings also have an incentive to inflate the offer price and increase their receipts from the sale of their shares.

Negotiations, 84 MICH. L. REv. 308, 311-19 (1985) (noting that plaintiffs' attorneys may use the class-action device to extract nuisance suit settlements from defendants).

${ }^{22}$ Others have noted the importance of new-growth companies for our economy. See, e.g., Anthony Q. Fletcher, Note, Curing Crib Death: Emerging Growth Companies, Nuisance Suits, and Congressional Proposals for Securities Liligation Reform, 32 HARV. J. ON LEGIS. 493, 495 (1995) ("Empirical data evinces that the confidence of venture capitalists in the securities markets is critical to the overall health and stability of the economy.").

${ }^{23}$ Several empirical phenomena exist in the new-issues market: new issues are often underpriced relative to initial market valuation; new issues systematically tend to underperform similarly situated stocks over the long term; the new-issues market is subject to hot issues periods of increased volume and underpricing. See Jay R. Ritter, The Long-Run Performance of Inilial Public Offerings, $46 \mathrm{~J}$. FIN. 3, 3 (1991) (stating that numerous studies have documented "the (shortrun) underpricing phenomenon" and "the 'hot-issue' market phenomenon"); Kevin Rock, Why New Issues Are Underpriced, 15 J. Fin. ECON. 187, 188 (1986) (recognizing the anomaly in the new-issues market that "shares appear to be issued at a discount").

${ }^{24}$ See Rock, supra note 23, at 187-93 (noting that it is not uncommon for issuers to receive exaggerated data regarding investors' interest in new shares).

${ }^{25}$ These agency problems arise among the issuing firm's managers, existing shareholders, and the new shareholders. 
Because of the importance of securities-fraud actions to the newissues market, this Article examines the incidence of securities class actions and reports their effect on the performance of IPOs from 1975 to $1986 .^{26}$ This Article tests the enforcement versus strike-suit theories of class actions and provides insights into the incentives of plaintiffs' attorneys in the IPO context. ${ }^{27}$

Several authors have studied shareholder suits in other contexts. ${ }^{28}$ Professor Romano analyzed a sample of 139 suits consisting of both derivative and direct shareholder suits. ${ }^{29}$ Because Romano did not treat the suits arising out of IPOs as a separate category, her article did not assess the impact of shareholder lawsuits on the new-issues market. Professors Drake and Vetsuypens $^{30}$ and Professor Alexander ${ }^{31}$ each specifically

${ }^{26}$ We stopped at 1986 to ensure that enough aftermarket data on stock price performance and on the incidence of suits was obtainable for each IPO within the sample.

${ }^{27}$ Relatively few attorneys specialize in complex securities class-action litigation. The major securities class-action plaintiffs' attorneys law firms are: Milberg, Weiss, Bershad, Specthrie \& Lerach (New York); Abbey \& Ellis (New York); Stull, Stull, \& Brody (New York); Berger \& Montague (Philadelphia); Much, Shelist, Freed, Denbenberg, Ament \& Eiger (Chicago); and Wolf, Popper, Ross, Wolf \& Jones (New York). See Macey \& Miller, supra note 18, at 67 n.197.

${ }^{28}$ In recent years, commentators have noted an increase in class-action suits based upon securities-fraud violations stemming from IPOs. See Michael Selz, Lawsuits Often Follow When Small Firms Go Public, WALL ST. J., Jan. 13, 1992, at B2. High-technology companies in particular have experienced a large increase in the number of securities class actions they face. See Ross Kerber, Shareholder Suits Prompt Reform Push: Company Officials Seek Laws to Limit Their Vulnerability, WASH. POST, Aug. 8, 1993, at H1; Wade Lambert, Corporate Settlement Costs Hit a Record, WALL ST. J., Mar. 10, 1995, at B3. The overall incidence of securities class actions, however, has not increased. See infra part II.A.I (reporting data on the incidence of securities class actions in our sample of IPOs). From 1990 to 1991, plaintiffs filed over 600 securities class-action complaints in federal courts-more than in the previous five years combined. See Selz, supra, at B2. Approximately a quarter of these cases were related to securities offerings. Companies settled in over $95 \%$ of these suits, often with liability insurers reimbursing most of the settlement costs. See id.; see also infra notes 73-75 and accompanying text (discussing liability insurance).

${ }^{29}$ See Roberta Romano, The Shareholder Suit: Litigation Without Foundation?, 7J.L. ECON. \& ORGANIZATION 55, 59 (1991). Romano tracked shareholder suits brought against a random sample of 535 New York Stock Exchange and Over-the-Counter firms from the late 1960s until 1987. These suits included suits dealing with acquisitions, takeover defenses, self-dealing, and securities-fraud-related complaints. Testing the efficacy of shareholder suits as a means of controlling managerial moral hazard, she found that although shareholder suits resulted in some structural changes, the suits overall acted as only a weak means of corporate governance. See id. at 80-85.

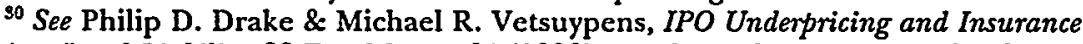
Against Legal Liability, 22 FIN. MGMT. 64 (1993). Drake and Vetsuypens also found that the median value of settlements as a percentage of aftermarket losses was $23.8 \%$. 
addressed the issue of shareholder litigation arising out of misstatements in IPO prospectuses. ${ }^{32}$ Alexander found some evidence that

See id. at 69.

${ }^{31}$ See Alexander, supra note 12, at 507-14.

32 Several other recent empirical studies have looked at the characteristics of fraud class actions in the general securities market context not specific to IPOs. These studies focused on only those firms that experienced a suit and did not examine those firms which did not get sued. The studies provided conflicting evidence as to the importance of merit in securities class-action settlements.

Jennifer Francis, Donna Philbrick, and Katherine Schipper conducted a study of the outcomes of 91 class-action suits brought under either Rule $10 \mathrm{~b}-5$ or section 11 of the Securities Act from 1988 to 1991. See Jennifer Francis et al., Determinants and Outcomes in Class Action Securities Litigation 1 (Aug. 1994) (unpublished manuscript, on file with authors). Looking only at the computers, chemicals, electronics, and retailing four-digit Standard Industry Classification (SIC) codes, they did not restrict their suits to IPO securities class actions. See id. at 2. Matching their suits with industry peer firms and size-matched firms, they found that lawsuit firms tended to be larger than their industry peers. Furthermore, firms in the lawsuit sample were more likely to have been audited by the Big Six accounting firms in the industrywatched control group. See id. They also found no evidence that lawsuit firms experienced more volatile returns or poorer financial performance, although lawsuit firms did have higher systematic risk. See id. at 3. Looking at measures of companyinitiated disclosure and outsider-initiated disclosure, they found significantly higher levels of disclosure for lawsuit firms than both industry and size-matched peer firms. Finally, they found that damages were related in a nonlinear fashion to settlement amounts. See id. at 4.

Frederick $C$. Dunbar and Vinita $M$. Juneja studied the factors driving settlement in securities class actions. Looking at 334 securities class actions between July 1991 and June 1993, they found that the three main factors driving settlement were stock price volatility, availability of assets, and merits of the case. In their test of the merits, they looked at two different merit measures. First, they found that the presence of a \$ 11 claim did not affect the overall settlement amount. Second, they found that concurrent government enforcement did not increase the settlement amount. Taking both the presence of a $\S 11$ claim and government enforcement as merit-related factors, they concluded that of the three factors affecting the settlement amount, merit was the least important. See Frederick C. DUNBAR \& VINITA M. JUNEJA, NATIONAL ECONOMIC RESEARCH Associates, INC., REcENT TRENDS II: What EXPLAINS SETtLements in ShaReHOLder Class ACTIONS 21 (1993).

A study by Vincent E. O'Brien collected a sample of 330 securities class actions from 1988 to 1991. O'Brien found that almost all of these cases settled; institutional investors received most of the benefits from the settlements, and attorneys received about $21 \%$ of the settlement amounts as their fees. O'Brien further found that the suits were spread across a wide variety of different industry groups, different revenue size firms, and firms of different ages. All lawsuit firms, however, did experience a large drop in their stock price immediately prior to the suit. See Vincent E. O'Brien, The Class-Action Shakedown Racket, WALL ST. J., Sept. 10, 1991, at A20.

Zoe-Vonna Palmrose examined the nature of the joint and several liability of auditors in securities-fraud claims. Her sample consisted of 227 instances of alleged audit failure involving the largest U.S. audit firms. She found that many claims against auditors were "weak" in the sense that awards were only rarely paid out. Rather, auditors were often dragged into litigation at high cost to the auditor under the joint and several liability rule by plaintiffs' attorneys fishing for some damages 
shareholder suits, at least against computer-related IPOs, were frivolous. Lawsuit IPO firms in her sample eventually settled for essentially the same percentage of their maximum potential damages award. ${ }^{33}$ From this finding, Alexander concluded that the merits do not affect the settlement amount. The small size of Alexander's sample (seventeen IPOs), ${ }^{34}$ however, makes it difficult to draw inferences about the incidence of litigation or the significance of her findings. Drake and Vetsuypens examined ninety-three IPOs which faced securities class actions between 1969 and $1990 .^{35}$ A number of authors have suggested that underwriters may underprice IPOs to avoid lawsuits. ${ }^{36}$ To test this theory, Drake and Vetsuypens compared the initial returns of firms that experienced a lawsuit against a control group of IPO firms. They found no evidence that firms experiencing lawsuits had less underpricing than

award or settlement. See Zoe-Vonna Palmrose, The Joint E Several vs. Proportionate Liability Debate: An Empirical Investigation of Audit-Related Litigation, 1 STAN.J.L. BUS. \& FIN. 53, 57, 67-68 (1995).

Steven Marino and Renée Marino examined a sample of 229 federal and state securities law settlements from April 1989 through February 1994 in which accountants, attorneys, or underwriters were sued. They divided their sample into those firms involved in "flagrant fraud" and those firms involved in less egregious instances of fraud. See Steven P. Marino \& Renée D. Marino, An Empirical Study of Recent Securities Class Action Settlements Involving Accountants, Attormeys, or Underwriters, 22 SEC. REG. L.J. 115, 124 (1994) ("Flagrant fraud . . . is an intentional breaking of the law by, for example, trading on insider information, fabricating invoices, or transferring company funds to personal Swiss bank accounts."). Using this division, they found that accountants contributed more than five times to settlement funds in cases involving "flagrant fraud" than other cases. This they found statistically significant at more than the $99 \%$ confidence level. From this, they concluded that merit played a factor in determining the size of settlement amounts. See id. at 141-42.

For a critique of several recent empirical studies on securities class actions, see Seligman, supra note 18, at 450-57. See also Andrew Rosenfield, An Empirical Test of Class-Action Settlement, 5 J. LEGAL STUD. 113, 116-17 (1976) (finding that in a sample of 104 class actions, plaintiffs' attorneys earned a statistically significant "settlement premium" for settled rather than litigated cases).

${ }^{33}$ See Alexander, supra note 12, at 517.

s4 See id. at 510-11.

${ }^{35}$ See Drake \& Vetsuypens, supra note 30, at 64.

${ }^{36}$ The lower the offering price, the less chance aftermarket trading will go below this offering price to expose the underwriter to the possibility of suit. Similarly, the lower the offering price starts, the greater the initial trading jump in the stock price, which juries may view as evidence that the issue was not overpriced at the time of the offering. See Janet C. Alexander, The Lawsuit Avoidance Theory of Why Initial Public Offerings Are Underpriced, 41 UCLA L. REV. 17, 66-72 (1993) (noting the relationship between the IPO price and the likelihood of legal action); Drake \& Vetsuypens, supra note 30, at 64 (saine); Seha M. Tiniç, Anatomy of Initial Public Offerings of Common Stock, 43 J. FIN. 789, 795 (1988) (same). 
firms not experiencing suits. ${ }^{37}$ Furthermore, unlike Alexander, they found that the settlement percentage of the aftermarket losses varied widely among the lawsuit IPO firms. ${ }^{38}$ Drake and Vetsuypens's study does not provide insights into the incidence of shareholder litigation. Moreover, because their sample is composed of cases with reported decisions or settlements, it is biased toward cases involving important decisions and those cases which were not dropped by plaintiffs.

This Article seeks to extend the previous empirical shareholder litigation work and provide a broad-based examination of securities class actions in the new-issues market. Because we look at the entire sample of equity IPOs from 1975 to 1986, we avoid the small sample size problems of Alexander's study and the bias problems of. Drake and Vetsuypens's work. Importantly, unlike other previous empirical work, we focus not only on those firms that were sued but also on those firms that were not sued. In fact, 3396 IPOs in our sample of 3519 IPOs were not subjects of lawsuits. Through a comparison of the differences between the two sets of firms, we hope to test more accurately the enforcement versus strike-suit theories. Part I introduces the enforcement versus strike-suit theories of securities class actions. Part II describes the empirical sample of IPOs used in our study. We provide several summary statistics of the IPO sample and the incidence of suits in Part II as well as the implications for plaintiffs' attorneys' incentives and the overall level of private securities law enforcement. Part III presents our tests of the enforcement against the strike-suit theories of securities-fraud class actions.

\section{The EnForcement Versus the Strike-Suit Theories}

Administered and enforced by the Securities Exchange Commission (SEC), the Securities Act of 1933 (Securities Act) ${ }^{39}$ and the Securities Exchange Act of 1934 (Exchange Act) ${ }^{40}$ regulate the initial public offerings process. The Securities Act, the Exchange Act, and their related rules comprise a complex body of law aimed at ensuring the adequate disclosure of information in securities transactions to protect the interests of securities market partici-

${ }^{37}$ See Drake \& Vetsuypens, supra note 30, at 69-70.

${ }^{38}$ See id. at 69.

3915 U.S.C. $\$ \S 77 a-77 a a(1994)$.

${ }^{40} 15$ U.S.C. $\$ \S 78 a-78 l l$ (1994). 
pants. The securities laws adopt a market corrective approach, seeking to enhance market efficiency through the dissemination of information rather than through the direct regulation of the capital markets.

While the SEC may initiate criminal and civil suits against firms for securities law violations, ${ }^{41}$ private plaintiffs-including purchasers in IPOs-also possess several avenues to obtain damages awards from the issuing team ${ }^{42}$ involved in a fraudulent offering of securities. IPO securities-fraud class-action plaintiffs may bring misrepresentation or omission claims under the following federal causes of action: (1) section 11 of the Securities Act; ${ }^{43}$ (2) section 12(a)(2) of the Securities Act; ${ }^{44}$ and (3) Rule $10 \mathrm{~b}-5^{45}$ under section 10(b) of the Exchange Act. Each cause of action has its own particular restrictions and requirements as well as potential damages awards. Liability under these provisions is contingent upon the basic requirement of some omission or misrepresentation of a material fact by the issuers in the public offering. Because actions in the IPO context are most commonly filed under section $11^{46}$ and

"See supra note 19 (describing SEC enforcement powers).

12 The issuing team includes the issuer, the underwriters, the auditors, and the attorneys involved in the IPO.

13 15 U.S.C. \$77k (1994).

1415 U.S.C. $\$ 77 l$ (1994), amended by Private Securities Litigation Reform Act of 1995, Pub. L. No. 104-67, sec. 105, 109 Stat. 737, 757.

1517 C.F.R. $\$ 240.10$ b-5 (1995).

${ }^{16}$ Section 11 applies only to securities offerings which the Securities Act requires to be registered with the SEC. See 15 U.S.C. § 77k. Section 11 becomes enforceable after the registration statement becomes effective and requires that some part of the statement contain a material misrepresentation or omission of a fact necessary to make statements in the document not misleading. See 15 U.S.C. $\$ 77 \mathrm{k}(\mathrm{a})$. Section 11 allows plaintiffs to sue the signers of the registration statement, principal officers of the issuer, directors of the issuer at the time of filing of the registration statement with the SEC, accountants, engineers, appraisers, other professional experts who prepare or certify a part of the registration statement, and underwriters. See Securities Act $\$ 11(a)(1)-(5), 15$ U.S.C. $\$ 77 k(a)(1)-(5)$. All defendants may be held jointly and severally liable. See Securities Act $\$ 11(f), 15$ U.S.C. $\$ 77 \mathrm{k}(\mathrm{f})$, amended by Private Securities Litigation Reform Act of 1995, Pub. L. No. 104-67, sec. 201(b), $\S 11(\mathrm{f}), 109$ Stat. 737, 761. Under section 11 , the issuer is liable even in the absence of scienter or negligence. See 15 U.S.C. $\$ 77 \mathrm{k}(\mathrm{a})$; LOUIS LOSS \& JOEL SELIGMAN, FUNDAMENTALS OF SECURTYY REGULATION 1005 (3d ed. 1995). Nonissuer defendants may, however, claim a "due diligence" defense. See Securities Act § I1(b), 15 U.S.C. $\S 77 \mathrm{k}(\mathrm{b})$.

Section 11 misrepresentations or omissions must be material. Material facts include those matters about which an average, prudent investor would reasonably wish to be informed before making a trading decision involving the registered securities. See, e.g., Lucia v. Prospect St. High Income Portfolio, Inc., 36 F.3d 170, 175 (1st Cir. 1994) (stating that "information is 'material' only if its disclosure would 
Rule $10 \mathrm{~b}-5^{47}$, this Article will focus on these two provisions.

alter the 'total mix' of facts available to the investor" and noting that this materiality test is "clearly enunciated in our case law"); Kronfeld v. Trans World Airlines, 832 F.2d 726, 731 (2d Cir. 1987) (stating that information is material if there is a substantial likelihood that a reasonable shareholder would consider it important in making an investment decision). Section 11 does not require that a plaintiff prove actual reliance. Defendants, however, may defend themselves against liability if they can establish that the plaintiff actually knew of the falsity or omission when the plaintiff bought the security. The Securities Act also provides that defendants may shift the burden of showing reliance to the plaintiffs if the defendants can demonstrate that the plaintiffs bought their securities after the issuer had made generally available to all its security holders an earnings statement covering at least the 12 months after the effective date of the registration statement. See Securities Act $\$ 11(\mathrm{a}), 15$ U.S.C. $\$ 77 \mathrm{k}(\mathrm{a})$. Furthermore, section 11 does not require plaintiffs to prove causation between the misrepresentation or omission and the price decline in the IPO stock. See Loss \& SELIGMAN, supra, at 1004 ("[I]nstead of the plaintiff's having to prove causation, damages are reduced to the extent that the defendant proves that they did not result from his or her misconduct ...."). The defendant may reduce the damages amount, however, by proving that some or all of the price decline was due to other exogenous factors. See Securities Act \$ 11(e), 15 U.S.C. $\$ 77 \mathrm{k}(\mathrm{e})$ (1994). Section 11 suits are subject to a two-part statute of limitations. Plaintiffs have up to one year to file suit after they discover or should have discovered through reasonable diligence the falsehood or omission. Plaintiffs also must file suit within three years after the closing date of the public offering. See Securities Act § 13, 15 U.S.C. $\$ 77 \mathrm{~m}$ (1994).

${ }^{47}$ Rule 10b-5 states:

It shall be unlawful for any person, directly or indirectly, by the use of any means or instrumentality of interstate commerce, or of the mails or of any facility of any national securities exchange, (a) [t]o employ any device, scheme, or artifice to defraud, (b) [t]o make any untrue statement of a material fact or to omit to state a material fact necessary in order to make the statements made, in the light of the circumstances under which they were made, not misleading, or (c) [t]o engage in any act, practice, or course of business which operates or would operate as a fraud or deceit upon any person, in connection with the purchase or sale of any security.

17 C.F.R. § $240.10 \mathrm{~b}-5$ (1995).

Although not specific to public offerings, Rule $10 \mathrm{~b}-5$ provides plaintiffs with potentially the broadest reach for securities liability. The set of potential defendants reached under Rule $10 \mathrm{~b}-5$ extends well beyond that of section 11 to cover any perpetrator of or participant in fraudulent activity "in connection with the purchase or sale of any security." Id. Courts have found activities by defendants to be "in connection" with the purchase or sale by the plaintiff of a security in cases where the defendant merely disseminated false or misleading statements into the market through a press release or other means reasonably calculated to affect investors engaged in trading the security on the open market. See SEC v. Texas Gulf Sulphur Co., 401 F.2d 833, 858-61 (2d Cir. 1968), cert. denied, 394 U.S. 976 (1969). Furthermore, Rule $10 \mathrm{~b}-5$ covers not only registered public offerings but also extends to security transactions in secondary market trading. See Superintendent of Ins. v. Bankers Life \& Casualty Co., 404 U.S. 6, 10 (1971) ("[T]he fact that the transaction is not conducted through a securities exchange or an organized over-the-counter market is irrelevant to the coverage of $\S 10(\mathrm{~b}) . "$ ). 
Section 11 and Rule 10b-5 suits are often brought through the class-action mechanism and serve as complementary causes of action for securities investor-plaintiffs. Unlike Rule 10b-5 which has a potentially broader scope of liability, section 11 renders it easier for investor-plaintiffs to prove their prima facie case. Furthermore, section 11 does not require a plaintiff to prove scienter, reliance, or causation. The defendant issuing team may rebut section 11's presumption of reliance and protect themselves against liability through due diligence; the burden of proof, however, rests with the defendants. ${ }^{48}$

In a typical securities-fraud class-action suit, plaintiffs' attorneys control the filing, prosecution, and settlement of the action. ${ }^{49}$

The elements of a Rule $10 \mathrm{~b}-5$ action are as follows. First, the implied right to damages available to private plaintiffs under Rule $10 \mathrm{~b}-5$ is available only to purchasers or sellers of securities involved in the transaction in question. See Blue Chip Stamps v. Manor Drug Stores, 421 U.S. 723, 753-55 (1975). Second, Rule 10b-5 liability requires that plaintiffs prove scienter on the part of the defendants. See Ernst \& Ernst v. Hochfelder, 425 U.S. 185, 201-15 (1976). Third, as in section 11, the plaintiff under Rule 10b-5 must show the defendants' misrepresentation or omission was material. See Basic Inc. v. Levinson, 485 U.S. 224, 230-32 (1988). Fourth, Rule 10b-5 liability requires that the plaintiff prove that she actually relied on the falsehood or omission to her detriment. See List v. Fashion Park, Inc., 340 F.2d 457, 462 (2d Cir. 1965). Note, however, that under the "fraud-on-the-market" theory, courts often presume investor reliance on the validity of the market price. See, e.g., Basic, 485 U.S. at 246-47 ("Because most publicly available information is reflected in market price, an investor's reliance on any public material misrepresentations, therefore, may be presumed. . . ."). Fifth, the plaintiff must show a causal link between the defendants' actions and the plaintiff's injury. Defendants may, however, argue that other exogenous factors helped cause the aftermarket price decline and seek to limit damages as a result. See, e.g., Jon Koslow, Note, Estimating Aggregate Damages in ClassAction Litigation Under Rule 10b-5 for Purposes of Setllement, 59 FORDHAM L. REv. 811, 817 \& n. 27 (1991) ("[T]he connected elements of materiality, reliance and causation require that damages calculations under Rule $10 \mathrm{~b}-5$ exclude the effects of market fluctuations unrelated to the fraud or misrepresentation.").

Until recently, no explicit Rule 10b-5 statute of limitations existed for private causes of action. In 1991, however, the Supreme Court in Lampf, Pleva, Lipkind, Prupis \& Petigrow v. Gilbertson, 501 U.S. 350, 359 (1991), held that in private Rule $10 \mathrm{~b}-5$ causes of action, plaintiffs have up to one year to file suit after they learn or reasonably should have learned of the misrepresentation or omission. Plaintiffs must also file within three years after the alleged misrepresentation or omission took place.

${ }^{18}$ See supra note 46 (summarizing the defenses against section 11 liability).

19 The Private Securities Litigation Reform Act may significantly change the securities class-action process. See Private Securities Litigation Reform Act of 1995, Pub. L. No. 104-67, 109 Stat. 737 (amending the Securities Act and the Exchange Act). This Article deals only with securities class actions prior to the Reform Act and does not address the its impact.

Many have commented on the agency problems the plaintiff' class has in monitoring and controlling its plaintiffs' attorneys. See Elliott J. Weiss \& John S. Beckerman, Let the Money Do the Monitoring: How Institutional Investors Can Reduce 
Plaintiffs' attorneys use Quotrons and other information devices to monitor stock prices carefully. ${ }^{50}$ Suits often follow large, precipitous drops in a company's stock price. Some argue that plaintiffs' attorneys, as a rule, automatically file suit after a ten-percent drop in a company's stock price. ${ }^{51}$ Plaintiffs' attorneys race with one another to file suit. Often, several securities class actions are filed at once against a particular defendant. These suits are then consolidated and transferred to one federal district court. ${ }^{52}$ Filing the first suit increases a plaintiffs' attorney's chances of securing the role as lead class counsel. ${ }^{53}$ Many class-action suits are filed within days, sometimes even hours, of a large security price drop. ${ }^{54}$

Agency Costs in Securities Class Actions, 104 YALE L.J. 2053, 2064-79 (1995). Indeed, Weiss and Beckerman even propose that procedural barriers to institutional investor participation as the class representative be reduced to encourage these investors to monitor plaintiffs' attorneys' activities more diligently. See id. at 2105-09. Although institutional investor participation may reduce the agency problem between plaintiffs' attorneys and the plaintiffs' class, this will not help reduce the incidence of frivolous suits. Plaintiffs, just as much as plaintiffs' attorneys, gain from a frivolous suit ex post. Once an investor owns stock in a corporation and the stock value plummets, the investor benefits from pursuing a positive-value frivolous suit. This is even true for investors who would value eliminating the threat of frivolous suits ex ante. So long as frivolous suits are still possible ex post, these investors will always wish some return for their investment, even through a frivolous suit.

${ }^{50}$ See Weiss \& Beckerman, supra note 49, at 2060-62; see also Private Litigation Under the Federal Securities Laws: Hearings Before the Subcomm. on Securities of the Senate Comm. on Banking, Housing, and Urban Affairs, 103d Cong., 1st Sess. 24, 109 (1993) (testimony of Richard J. Egan, Chairman of EMC Corporation) ("We think [the plaintiffs' attorneys'] Quotrons are connected to their word processor.").

${ }^{51}$ William Lerach, however, presents counterevidence that most firms which experience a $10 \%$ drop in their stock price in one day are not sued under federal securities laws. See Lerach, supra note 14, at 26-28.

${ }^{52}$ See Weiss \& Beckerman, supra note 49, at 2062.

${ }^{53}$ Many courts will simply appoint the plaintiffs' attorney who files first as lead counsel. See id. at 2062-63 nn.41-44; see also Alexander, supra note 12, at 513-14 (arguing that the pressure on plaintiff' attorneys to file first results in little prefiling screening of potential securities defendants). Other courts allow the plaintiffs' attorneys to decide for themselves who will become lead counsel. Filing first under this system allows a plaintiffs' attorney to copy his complaint for other plaintiffs' attorneys. These other plaintiffs' attorneys then also file suit separately, sharing in the expected fee award and granting their support to the initial plaintiffs' attorney's selection as lead counsel. See Weiss \& Beckerman, supra note 49, at 2063. Recently, however, at least one court has auctioned the lead counsel position to the lowest feebidding plaintiffs' attorney. See In re Wells Fargo Sec. Litig., 157 F.R.D. 467, 476 (N.D. Cal. 1994). For an analysis of the implications of auctioning the lead counsel position, see John C. Coffee, Jr., Regulating Plaintiffs' Attorneys, N.Y. L.J., Sept. 22, 1994 , at 5.

${ }^{54}$ See Weiss \& Beckerman, supra note 49, at 2060 \& n.32. 
Because the lead counsel often grabs the lion's share of the fees, the incentive to file first is considerable. ${ }^{55}$

In order to increase their ability to react quickly to stock price declines, plaintiffs' attorneys often maintain a stable of willing potential plaintiffs' representatives in case the price of a particular security drops. ${ }^{36}$ The numbers of different plaintiffs' attorneys and different plaintiff's class representatives are remarkably limited. ${ }^{57}$ There exist only relatively few plaintiffs' attorney firms. ${ }^{58}$ Similarly, there are only a few people who repeatedly play the role of plaintiffs' representative. ${ }^{59}$ These small numbers give plaintiffs' attorneys great control over the class action. Given this framework of securities litigation, this Part briefly reviews strike-suit

${ }^{55}$ See, e.g., Garr v. U.S. Healthcare, Inc., 22 F.3d 1274, 1277 (3d Cir. 1994) ("The lead attorney position is coveted as it is likely to bring its occupant the largest share of the fees generated by the litigation."). Lead counsel can claim most of the fees by assigning herself most of the work in prosecuting the class action. See Weiss \& Beckerman, supra note 49, at 2062.

The Reform Act also reduces the incentives of being lead plaintiff. See Private Securities Litigation Reform Act of 1995, Pub. L. No. 104-67, sec. 101, 109 Stat. at 738-49 (to be codified at Securities Act $\$ 27,15$ U.S.C. $\$ 77 \mathrm{z}-1$, and Exchange Act § $21 \mathrm{D}, 15$ U.S.C. § 78u-4); see also supra notes 13-17, 49 and accompanying text (discussing some of the changes of the Reform Act).

${ }^{56}$ See Jonathan M. Moses, Lawyer Given to Filing Shareholder Lawsuits Comes Under Scrutiny, WALL ST. J., Oct. 28, 1992, at A1, A13 (reporting that some securities plaintiffs' attorneys maintain lists of potential class representatives). Weiss and Beckerman argue that plaintiffs' attorneys without their own stable of willing class representatives must rely on an intermediary with a similar stable of shareholders. Otherwise, such plaintiffs' attorneys would be at a disadvantage in pursuing a class action relative to competing attorneys with ready access to possible plaintiffs' representatives and would be unable to file a complaint within only a few days of relevant corporate announcements. See Weiss \& Beckerman, supra note 49, at 2061 n.35.

${ }^{57}$ Cf. Coffee, Rethinking the Class Action, supra note 21, at 634 ("[B]ecause the process by which a cheap settlement can be exchanged for a high fee award necessarily involves at least a tacit understanding within the plaintiff's attorneys' camp, such an agreement can most easily develop among 'repeat players' who know and can trust each other."). For a detailed examination of the securities class-action litigation process, see Weiss \& Beckerman, supra note 49, at 2058-64. firms).

${ }^{59}$ See supra note 27 (listing major securities class-action plaintiffs' attorneys law

${ }^{59}$ For example, William B. Weinberger has served as plaintiffs' class representative in numerous securities-fraud litigations. In our sample of lawsuits, Weinberger appeared over 10 times. Others have found similar results: Harry Lewis was a named plaintiff in an estimated 300-400 securities suits; Steven Cooperman was a plaintiff in 19 suits; Rodney Shields was a plaintiff in 20 suits; and Weinberger himself appeared in more than 90 securities class actions before his death. See Robert Mednick \& Jeffrey J. Peck, Proportionality: A Much-Needed Solution to the Accountants' Legal Liability Crisis, 28 VAL. U. L. REV. 867, 904-05 n.129 (1994). 
and enforcement theories relating to IPO securities class-action suits.

\section{A. The Strike-Suit Theory}

Securities class actions may equip opportunistic plaintiffs and their attorneys with a powerful device to extract value from poorly performing IPOs. ${ }^{60}$ Several commentators have written on the incentives of plaintiffs (or their attorneys) to file suit solely to obtain settlement in cases where the expected value to plaintiffs from going to trial is negative ("NEV suits"). ${ }^{61}$ Professors Rosenberg and Shavell, for example, hypothesize that NEV suits exist because defendants are willing to pay plaintiffs up to the sum of the defendants' litigation, distraction, and reputation costs ${ }^{62}$ from answering the plaintiffs' complaint and obtaining a dismissal. ${ }^{63}$ In cases where plaintiffs enjoy a significant initial cost advantage over defendants in conducting a lawsuit, ${ }^{64}$ defendants are often willing to settle to avoid the actual costs of defending against the frivolous

${ }^{60}$ See supra note 21 and accompanying text (citing others who argue that securities class actions are largely frivolous); see also Joseph A. Grundfest, Why Disimply?, 108 HARV. L. REV. 727, 730-47 (1995) (arguing that frivolous suits do exist and that more empirical analysis of these suits needs to be performed).

${ }^{61}$ It is at first unclear why plaintiffs would file an NEV suit. To the extent defendants realize that plaintiffs are filing an NEV suit, defendants will also know that the plaintiffs' threat of going to trial is not credible. All defendants need do is sit and wait; rational plaintiffs will then drop suit rather than face an NEV trial. In game theory terms, it is not subgame perfect for plaintiffs to threaten to go to trial in situations where they will receive a negative return from trial. The NEV models developed below in the text and notes attempt to demonstrate why NEV suits may still occur despite this subgame perfection problem.

62 The cost and distraction of defending a securities-fraud class-action suit can be considerable. See Paul Sweeney, Full Siege Ahead, ACROSS THE BOARD, Nov.-Dec. 1994, at 30, 32 (citing an American Express study that found that $70 \%$ of CEOs involved in pending lawsuits spent a full day each week supervising these suits).

${ }^{63}$ See David Rosenberg \& Steven Shavell, A Model in Which Suits Are Brought for Their Nuisance Value, 5 INT'L REV. L. \& ECON. 3, 3-4 (1985) (developing a formal model of nuisance suits based on the plaintiffs' ability to exploit a significant initial cost advantage in conducting a lawsuit).

64 Professor Coffee writes, "[I]t is far simpler to demand that the defendant identify and furnish all documents, memoranda, letters and conversations conceivably pertaining to a particular subject matter over a multi-year period than it is to comply with such a demand." See Coffee, Rethinking the Class Action, supra note 21, at 637; see also Weiss \& Beckerman, supra note 49, at 2086 (contending that the cost of litigation is higher for defendants than plaintiffs). Under this theory, the maximum amount for which a defendant would be willing to settle a frivolous suit equals the amount saved from not having to defend against the suit. 
suit. ${ }^{65}$ Similarly, Professor Bebchuk argues that NEV suits may bring positive returns to plaintiffs where defendants are uncertain whether they face an NEV or positive expected value (PEV) suit for the plaintiff. ${ }^{66}$ Because PEV suits will definitely go to trial, settlements save defendants their full litigation-related costs. As a result, defendants settle even NEV suits depending on the fraction of suits that actually are NEV suits and on the litigation costs saved from avoiding trial.

Importantly, a suit may have a negative expected value from trial either, because the expected damages to the plaintiffs are low or because the costs of litigation are high for the plaintiffs. As a result, two types of NEV suits exist: those without any merit and those where the merit is outweighed by the plaintiffs' litigation costs. Most would agree that purely meritless NEV suits fit the common definition of "strike suits." On the other hand, settlements of noncost-justified, merit-based NEV suits somewhat penalize defendants and may actually benefit social welfare to the extent the settlement payments track the level of merit in the NEV suits. In the Shavell and Rosenberg and the Bebchuk models, however, settlement amounts depend primarily on the costs of litigation. ${ }^{67}$ Therefore, the deterrence aspect of meritorious NEV suits does not directly relate to merit and may result in more social loss through overdeterrence than the underdeterrence loss which would result from banning NEV suits. This Article, therefore, treats all NEV suits as strike suits. ${ }^{68}$ The Rosenberg and Shavell and the Bebchuk models predict that the incidence of NEV suits does not turn on the merits of a particular case, but rather on the costs of litigation and on the degree of uncertainty defendants have in distinguishing NEV

${ }^{65}$ See Rosenberg \& Shavell, supra note 63, at 3-4.

${ }^{66}$ See Lucian A. Bebchuk, Suing Solely to Extract a Settlement Offer, $17 \mathrm{~J}$. LeGal STUd. 437, 437-41 (1988); Avery Katz, The Effect of Frivolous Lawsuits on the Settlement of Litigation, 10 INT'L REV. L. \& ECON. 3, 5 (1990). See generally Robert D. Cooter \& Daniel L. Rubinfeld, Economic Analysis of Legal Disputes and Their Resolution, 27 J. ECON. LIT. 1067, 1075-82 (1989) (providing a summary of settlement theories).

${ }^{67}$ In Bebchuk's model, the amount NEV suit plaintiffs receive depends not only on the litigation costs, but also on the proportion of NEV suits in the population of potential suits facing defendants. The higher the proportion of NEV suits, the lower the amount for which defendants are willing to settle. See Bebchuk, supra note 66, at 446-47.

${ }^{68}$ Furthermore, to the extent NEV suits bring positive returns to plaintiffs (and their attorneys), plaintiffs with completely meritless actions will have an incentive to increase the number of suits they file. In equilibrium, therefore, the proportion of meritless suits will rise. 
from PEV suits. ${ }^{69}$ Several of this Article's tests, therefore, focus on whether merit drives the incidence of suits.

In the initial public offering context, Alexander has developed her own particular form of the strike-suit theory, arguing that strong incentives for both defendants and plaintiffs to settle an IPO securities class-action suit weaken the relationship between settlement amounts and the merits. ${ }^{70}$ She claims that defendants strongly desire to settle and avoid trial for several reasons. Given the substantial downside risk of judgment at trial (due to the extremely large potential damages awards common in IPO suits), directors and officers of the issuer do not wish to go to trial. ${ }^{71}$ Moreover, defendants concerned about their reputation in the public offerings market may desire to avoid the negative publicity accompanying a trial. ${ }^{72}$ Defendants may also prefer a settlement because the issuer's directors and officers often have liability insurance policies or because the issuer indemnifies directors and officers for any securities settlement they make. ${ }^{73}$ Insurance or

${ }^{69}$ It is possible to modify Bebchuk's model to make the merits matter to some extent even for NEV cases. Defendants may possess some level of information on the merits of a particular suit. This, in turn, may allow the defendants to make a more accurate assessment (through Bayesian updating) of the likelihood that the suit they face is merit based. For example, where the defendant knows that it committed gross securities fraud and can observe large stock price declines in the market resulting from this fraud, the defendant will believe that many cases against it are indeed PEV suits. Likewise, where the defendant knows that it committed no fraud, it will assess cases against it as mostly NEV suits. This assessment, in turn, will affect the amount, if any, defendants are willing to pay for NEV suits. To the extent NEV suits exist on a range, the NEV suits with higher levels of defendant-observable merit will receive higher amounts of settlements from defendants. Because this Article only tests for whether merit drives suits or not, these types of NEV suits are not distinguished.

${ }^{70}$ See Alexander, supra note 12 , at 504-07, 524-68. Note that in most standard models of settlement, the expected merits of the case at trial do effect the settlement amount. See George L. Priest \& Benjamin Klein, The Selection of Disputes for Litigation, $13 \mathrm{~J}$. LEgal STUd. 1, 4 (1984).

${ }^{71}$ This is an area of potential managerial moral hazard. Although it may be in the best interests of the issuing firm to go to trial and seek a judicial ruling, risk-averse officers and directors who control the firm may instead force the firm to settle. See Alexander, supra note 12 , at 529-30.

${ }_{72} \mathrm{See} i \mathrm{i}$. at 532 . Those concerned include the underwriters, accountants, and attorneys involved in the offering. This incentive applies especially to underwriters, who as repeat players in the initial public offering marketplace place a higher value on their reputation in the market than other IPO participants. But see id. at 558-60 (arguing that underwriters adopt a tough no-settlement stance to protect themselves against settlement awards by other defendants).

${ }^{73}$ Ninety-four percent of public companies with greater than 500 shareholders carry some form of directors' and officers' liability insurance (D\&O insurance). D\&O insurance is a factor in approximately $80 \%$ of shareholder litigation. Approximately 
indemnification provisions, in addition, often do not allow reimbursement to directors or officers after judgment at trial where culpability is found. ${ }^{74}$ Insurers will tend not to contest the settlement because refusal may result in a claim against them for badfaith refusal to settle; such a claim, if successful, would make the insurer liable for the entire amount of any eventual judgment regardless of the policy limits. ${ }^{75}$ Plaintiffs also have strong incentives to settle and avoid trial. First, plaintiffs and their attorneys may be risk averse. ${ }^{76}$ Second, in practice, plaintiffs' attorneys control the plaintiff class. ${ }^{77}$ Class members and their representa-

$50 \%$ to $80 \%$ of the settlement money in shareholder litigation comes from D\&O insurance. See $i d$. at 550 . D\&O insurance policies typically include a provision excluding liability arising from securities offerings. IPO plaintiffs can get around this exclusion by including claims for damages to aftermarket purchasers; such claims are not subject to this standard exclusion. See id. at 551 . Note that specific Securities Act insurance is sometimes available at a higher premium for issuers of public equity. Like D\&O insurance policies, such policies usually contain an exclusion for dishonesty or "actual or willful intent to defraud." Id. at $554 \mathrm{n} .231$.

${ }^{74}$ After an unfavorable judgment, D\&O insurers will often claim insurance fraud against the defendants, arguing that the defendants obtained the policy under fraudulent pretenses; in such situations, insurers will refuse to pay the insurance claim. See id. at 550-52; see also Romano, supra note 29, at 57 (arguing that "differential indemnification rights, insurance policy exclusions, and plaintiffs' counsel as the real party-in-interest create powerful incentives for settlement").

${ }^{75}$ See CAL. INS. CODE $\$ 790.03(\mathrm{~h})(5)$ (West 1989) (stating that insurers must "attempt[] in good faith to effectuate prompt, fair, and equitable settlements of claims in which liability has become reasonably clear"); see also David W. Ichel, Directors' and Officers' Insurance Coverage: An Overview and Current Problems, in DIRECTORS' AND OFFICERS' LIABILITY INSURANCE AND SELF INSURANCE 29, 44-45 (PLI Commercial Law \& Practice Course Handbook Series No. 381, 1986) (stating that insurers are generally obligated to defend an action or contribute to a defense unless the complaint is "patently groundless"); David B. Parker \& Linda Hulse Vitlin, The Role of Liability Insurance in Securities Litigation, in 1 SECURITIES LITIGATION, supra note 18, at 373, 375-76 (explaining the situations in which an insurer would not have to cover the liability of a corporation or corporate director).

${ }^{76}$ See Alexander, supra note 12, at 535-48 (explaining that plaintiffs' attorneys' desires to settle stem from their risk aversion); Lazos, supra note 21, at 313-15 (stating that both plaintiffs and attorneys have a motivation to settle to avoid the risk of bearing the high costs of trial). But see Coffee, The Unfaithful Champion, supra note 21, at 18-19 (arguing that as repeat players, plaintiffs' attorneys are more likely to be risk neutral than defendants).

${ }^{77}$ See Coffee, Rethinking the Class Action, supra note 21, at 627 ("Today, most observers would probably concede that some litigation contexts-most notably, derivative, securities, and antitrust litigation-are ones in which the plaintiff's attorney functions in such an 'entrepreneurial' mode . . . ."); Macey \& Miller, supra note 18, at 3 ('[P]laintiffs' class and derivative attorneys function essentially as entrepreneurs who bear a substantial amount of the litigation risk and exercise nearly plenary control over all important decisions in the lawsuit."). 
tives are too numerous and individually have too few incentives to oppose the wishes of plaintiffs' attorneys. While theoretically courts must review and authorize any class-action settlement, in practice courts almost always grant their approval. ${ }^{78}$ Plaintiffs' attorneys may settle even when doing so is not in their clients' best interests because the plaintiffs' attorneys are risk averse, the cost of going to trial is prohibitively high, ${ }^{79}$ or the defendant offers a large attorney fee award as part of the settlement. ${ }^{80}$

All these factors lead Alexander to a hypothesis different from that of either Rosenberg and Shavell or Bebchuk: ${ }^{81}$ Alexander claims not only that the incidence of litigation is unrelated to merits, but she also claims that settlement amounts turn on the level of potential damages rather than on the defendants' costs of litigation. ${ }^{82}$ To test her hypothesis, Alexander looked at all computer

Alexander notes that securities plaintiffs' attorneys are typically compensated under a "lodestar" arrangement which gives the attorneys a fee equal to the number of hours they work times a reasonable or customary wage. See Alexander, supra note 12, at 538. Because most of the attorneys' hours are put in pretrial and because trial puts the attorneys at risk of receiving nothing for their investment, plaintiffs' attorneys have a large incentive to settle in the securities area. See id. at 538-45; see also Hensley v. Eckerhart, 461 U.S. 424, 433 (1983) (recognizing the lodestar formula as the prevailing method for determining fee awards in contingency fee cases); Macey \& Miller, supra note 18, at 22-27 \& n.63 (noting that plaintiffs' attorneys compensated under a lodestar contingency fee arrangement will have an incentive "to settle for a relatively low sum on the eve of trial, knowing that in so doing they obtain most of the benefits they can expect from the litigation while eliminating their downside risk"). Some courts recently have shifted toward the "percentage" method of contingency fees (where the plaintiffs' attorneys are paid a percentage of the settlement or liability amount). See In re Oracle Sec. Litig., 131 F.R.D. 688, 689 (N.D. Cal. 1990) (noting that the lodestar approach is "now thoroughly discredited by experience").

${ }^{78}$ See Lawrence M. Grosberg, Class Actions and Client-Centered Decisionmaking, 40 SYRACUSE L. REV. 709, 739 (1989) ("[M]ost class settlements get approved with little objection and generally little judicial involvement."); Judith Resnick, Judging Consent, 1987 U. CHI. LEGAL F. 43, 101 ("[J]udges are ill-equipped to do much other than nod when the litigants join together and seek court approval.").

${ }^{79}$ Going to trial presents plaintiffs' attorneys with quantitatively and qualitatively different costs than pretrial activity. Trial work involves significantly more emotional stress and preparation than pretrial work.

${ }^{80}$ As part of the settlement, defendants will often agree not to contest the plaintiffs' attorneys' "lodestar" contingency fee award. See supra note 77; see also Romano, supra note 29, at 57 (noting that plaintiff' attorneys have a powerful incentive to settle shareholder suits to guarantee their attorneys' fees).

${ }^{81}$ The Rosenberg and Shavell and the Bebchuk models simply posit that settlements depend on the costs of litigation.

${ }^{82}$ See Alexander, supra note 12 , at 501-05, 517-19, 545-48. Alexander argues that defendant risk aversion will lead them to accept almost any settlement. Plaintiffs' attorneys, on the other hand, will not pursue settlements above the "going rate" 
and computer-related IPOs that went public during the first half of 1983, finding that all the IPOs in her sample (nine out of seventeen) that experienced a large enough loss in value (an aftermarket loss in excess of twenty million dollars) were sued. These suits eventually settled for approximately the same percentage of the decline in overall market value (roughly twenty-five percent of the potential damages award). ${ }^{83}$ Assuming that settlements would be for twenty percent of the decline in IPO stock value and that contingency fees would be for twenty-five to thirty percent of the award, Alexander calculated that plaintiffs' attorneys filed suit when their expected fee reached $\$ 1.25$ million and above. ${ }^{84}$ Alexander concluded that because the merits of the settled suits were unlikely to be the same and because all the suits settled for the same percentage of the potential damages award, merit did not constitute a factor in these settlements. $^{85}$

Alexander's empirical work, however, is unconvincing for two reasons. First, her sample of seventeen IPOs is too small to make inferences at any reasonable level of statistical significance. ${ }^{86}$ Our sample of 3519 IPOs attempts to remedy this defect in Alexander's work. Second, she selected only computer-related IPOs, which represent a biased cross-section of all the IPOs. As discussed below, computer-related IPOs, in fact, belong to the industry group (Standard Industry Classification (SIC) code 357) that experienced the highest rate of securities class-action suits. ${ }^{87}$ For our purposes, we'do not directly test Alexander's hypothesis on the settlement amounts in securities litigation, although we do provide some evidence in support of her theory; rather, our tests focus on whether merit drives the filing of suit.

because it allows them to maintain "larger portfolio[s] of cases that settle for a uniform rate" and eases settlement negotiations. See id. at 547.

${ }^{83}$ See id. at 513 n.46.

${ }^{84}$ See id.

${ }^{85}$ See id. at 522-23.

${ }^{86}$ See Seligman, supra note 18, at 453 (criticizing the small sample size of Alexander's study).

${ }^{87}$ Weiss and Beckerman also criticize Alexander's results, arguing that if the potential damages awards are reduced by the amount of damages the defendant could argue resulted from other factors (for example, a general decline in the industry stock index), then Alexander's result that the settlement amount was for a constant proportion of the potential damages award would disappear. See Weiss \& Beckerman, supra note 49 , at $2080-84$. 


\section{B. The Enforcement Theory}

Securities-fraud class actions, on the other hand, may serve a vital role in policing fraud in the securities markets. ${ }^{88}$ Proponents of fraud liability claim that securities class actions benefit both investors and the capital markets. Because private litigation provides protection, investors can invest with more confidence. Small investors in particular benefit because, although they depend heavily on the information company management provides, they lack the experience and sophistication to detect and filter out misleading corporate disclosures. ${ }^{89}$ Larger, more sophisticated investors, however, often possess alternative sources of information on investment prospects and can therefore make better educated decisions.

Fraud liability benefits capital markets to the extent investment funds shift to their highest value use. Reliance on misleading disclosure may cause some funds to shift toward companies whose true investment value is lower than that of other, more truthful companies. By reducing the amount of misleading disclosure, therefore, fraud liability results in a more efficient allocation of financial capital. ${ }^{90}$

The benefits of fraud liability depend on securities-fraud actions actually playing an enforcement role. ${ }^{91}$ Under the enforcement

${ }^{88}$ See supra note 18 (citing proponents of securities class actions).

${ }^{89}$ This is particularly true in the IPO context because no secondary market trading mechanisms exist to transmit the knowledge held by sophisticated investors to the market as a whole.

${ }^{90}$ Certainly, some level of misleading disclosure exists in the securities market. Outside the IPO context, the New York Times reported a widespread practice of companies falsifying corporate data. See Diana B. Henriques, Business Fraud of the 90's: Falsifying Corporate Data, N.Y. TIMES, Sept. 21, 1992, at Al ("[I]n the last year alone, at least 20 public companies traded on national stock exchanges have come forward to disclose serious lapses in their past financial statements ranging from inflated sales and hidden ownership to the possibility of outright embezzlement."); see also Beware of False Profits: The Temptation to Misstate Revenues Snags Young Firms, BOSTON GLOBE, June 1, 1994, at 29 (reporting that young, publicly held companies are more commonly "report[ing] sales of products or services that aren't completely sold-gambling that the transaction will be completed before the deception is detected or that another sale or contract with some upfront cash will cover the revenue shortfall").

${ }^{91}$ Anecdotal evidence exists that some suits are merit driven. In the Crazy Eddie case, for example, securities-fraud litigation helped reveal misleading disclosures, which led to criminal charges against the company's founder, Eddie Antar. See In re Crazy Eddie Sec. Litig., 824 F. Supp. 320, 322 (E.D.N.Y. 1993). Plaintiffs' attorneys in that case also assisted the government by locating and recovering assets Antar hid. See id. at 326. 
theory, circumstances specific to each particular case determine the damages award or settlement amount under section 11 and Rule $10 \mathrm{~b}-5 .^{92}$ Plaintiffs are more likely to succeed in cases, for example, where the issuer or underwriter blatantly introduces false projections in the registration statement than in cases involving alleged omissions where the defendants both lack scienter and conduct the IPO with due diligence. By carefully incorporating all relevant data and details into the registration statement and diligently researching the validity and accuracy of all statements, issuers and their agents should theoretically be able to protect themselves fully against legal liability. Legal liability, therefore, gives issuers an incentive ex ante ${ }^{93}$ to ensure that they make no material misstatements or omissions in the IPO registration statement or related communications. ${ }^{94}$

Not surprisingly, plaintiffs' attorney William S. Lerach has argued that plaintiffs' attorneys must invest substantial amounts of effort in examining the merits of a case before drafting a complaint. $^{95}$ Such a process requires substantial care due to the large

92 Several commentators have written on how the merits at trial affect the settlement amount for PEV suits. See William M. Landes, An Economic Analysis of the Courts, 14 J.L. \& ECON. 61, 66-69 (1971) (analyzing empirically the likelihood of trial versus settlement in the criminal context); William $M$. Landes \& Richard A. Posner, An Economic Approach to Legal Procedure and Judicial Administration, 2 J. LEGAL STUD. 399, 417-29 (1973); Steven Shavell, Suit, Settlement and Trial: A Theoretical Analysis Under Alternative Methods for the Allocation of Legal Costs, $11 \mathrm{~J}$. LEGAL STUD. 55, 63-69 (1982) (analyzing under four cost-allocation systems the likelihood of trial or settlement).

${ }^{93}$ Throughout this Article, "ex ante" refers to the time preoffering. "Ex post" refers to the time period after investors learn that a securities class action has been or will be filed against a particular IPO issuing team.

${ }^{4}$ See Private Litigation Under the Federal Securities Laws: Hearings Before the Subcomm. on Securities of the Senate Comm. on Banking, Housing, and Urban Affairs, 103d Cong., Ist Sess. 141, 145 (1993) (testimony of William S. Lerach) (arguing that private enforcement "is an essential supplement to Government enforcement of the securities laws, particularly in an era of deregulation and shrinking budgets"); see also Mitsubishi Motors Corp. v. Soler Chrysler-Plymouth, Inc., 723 F.2d 155, 168 (1st Cir. 1983) ( $[A] n$ investor . . . who brings an action under the securities laws serves the public interest by policing the securities market."), aff'd in part and rev'd in part on other grounds, 473 U.S. 614 (1985).

${ }^{95}$ See Lerach, supra note 18 , at $90-99$ (discussing the evaluation and investigation process by which a plaintiff' attorney should approach a potential securities case). Macey and Miller also argue that strike suits do not comprise a large portion of fraud class actions. See Macey \& Miller, supra note 18, at 78 ("Most observers agree that strike-suit litigation is relatively uncommon."). They contend that repeat-player defendants will not settle to avoid developing a "reputation as an easy mark" for frivolous litigation. See id. Similarly, plaintiffs' attorneys are unlikely to invest the substantial amount of money it takes to conduct a complex class action where the suit 
up-front costs plaintiffs' attorneys incur in pursuing a securities case on a contingent-fee basis. Lerach points out that because plaintiffs' attorneys must obtain court approval before they may drop items from a complaint, it serves their interests to examine the merits of the case thoroughly before filing. ${ }^{96}$ The "good faith" requirement of Federal Rule of Civil Procedure 11 gives plaintiffs' attorneys an additional incentive to investigate the merits of a case prior to filing a complaint. ${ }^{97}$ Moreover, a carelessly drafted complaint can jeopardize the chances that the court will certify the plaintiff class. Drafting a complaint that accurately reflects the source of the misstatements in the prospectus will ultimately reduce the amount of motions plaintiffs' attorneys must prepare after filing the complaint. According to the enforcement theory, therefore, plaintiffs' attorneys primarily file merit-based securities-fraud claims.

\section{SAMPle Selection Methodology and Data Description}

Our sample consists of 3519 initial public offerings of equity or limited-partnership units between January 1975 and December 1986. Professor Jay Ritter provided the data for the period between January 1975 and December 1984..$^{98}$ We obtained data on offerings between January 1985 and December 1986 from Going Public: The IPO Reporter ${ }^{99}$ and the Security Data Company's Mergers and Corporate Transactions database. ${ }^{100}$ We exclude real estate investment trusts, ${ }^{101}$ mutual funds, ${ }^{102}$ banks, thrifts, and their

is frivolous because of the high probability of no return for this investment. See id. ("The true strike suit, where it occurs, is unlikely to be overly costly for defendants because the plaintiff would be likely to settle at a very low figure.").

${ }^{96}$ See id. at 91.

${ }^{97}$ See id. at 93-94; see also FED. R. CIV. P. 11 (requiring attorneys to file court papers in good faith).

${ }^{98}$ This data was obtained directly from Professor Jay Ritter, University of Illinois at Urbana-Champaign.

${ }^{99}$ See 9-10 GoING PUBLIC: THE IPO REPORTER (1985-1986).

${ }^{100}$ Mergers and Corporate Transactions Database, Security Data Co., Newark, N.J. (Jan. 1985-Dec. 1986). The database is now known as SDC Worldwide Mergers and Acquisitions.

${ }^{101}$ Form S-11 is designed specifically for registration of securities that real estate investment trusts issue. It requires special disclosure regarding certain investment policies of the registrant. See Securities Act Form S-11, Fed. Sec. I. Rep. (CCH) 7233 (June 7, 1995). See generally 3A Sec. \& Fed. Corp. L. Rep. (Clark Boardman) 7-54.7 to -54.8 (1993) (describing the general disclosure requirements for real estate investment trusts).

102 The Investment Company Act of 1940, 15 U.S.C. $\$ 80 a-8$ (1994), supplements the existing disclosure requirements in the Securities Act for mutual funds. See 
respective holding companies ${ }^{103}$ because these institutions are subject to different disclosure requirements under the securities laws. The sample contains almost all firm-commitment offerings in the period from 1975 to 1986 and a large number of the best-efforts offerings undertaken between 1975 and $1985 .{ }^{104}$

To determine which firms faced class-action lawsuits, we examined annual disclosure forms (Form 10-K) filed with the SEC by each firm for the four-year period following the initial offering date. ${ }^{105}$ The securities laws require reporting firms to disclose all material legal proceedings-including shareholder litigation-in each $10-K .^{106}$ In the event that $10-K s$ were not available for a

Thomas P. Lemke \& Gerald T. Lins, Private Investment Companies Under Section $3(c)(1)$ of the Investment Company Act of 1940, 44 Bus. LAw. 401, 401 (1989) (noting that before disclosure requirements of the Investment Company Act, "investment companies were particularly prone to manipulation, self-dealing and other misfeasance ${ }^{n}$ because of the liquid nature of their assets). The Investment Company Act of 1940 has a registration statement for open-end management companies (e.g., mutual funds)-Form N-1A. See Investment Company Act of 1940 Form N-1A, Fed. Sec. L. Rep. (CCH) I 51,201 (Sept. 20, 1995).

${ }^{103}$ Banks and thrifts are exempt from the registration and reporting requirements, but not the antifraud provisions, of the Securities Act. See Securities Act $\S 3,15$ U.S.C. \$ 77c (1994); see also LOSS \& SELIGMAN, supra note 46, at 218-21, 272-73.

${ }^{104}$ The Ritter data set contains most firm-commitment and best-efforts IPOs undertaken on major exchanges between 1975 and 1984. The IPO Reporter listed both firm-commitment and best-efforts offerings for 1985 but only firmcommitment offerings in 1986. Mergers and Corporate Transactions listed only firmcommitment IPOs. Thus, our sample includes almost all significant offerings of either type between 1975 and 1985 and almost all firm-commitment offerings made in 1986.

${ }^{105}$ Issuers listed on a national exchange and issuers with greater than $\$ 1$ million in assets and with at least 500 shareholders in a given class of equity must make periodic reports to the SEC. See Exchange Act $\$ \S 12,13,15$ U.S.C. $\$ \S 78 l, 78 \mathrm{~m}$ (1994). Also, all IPO issuers must make the same periodic reports for at least their first fiscal year after the offering and each subsequent year where the number of shareholders in any given class remains above 300. See Exchange Act $\S 15(d), 15$ U.S.C. $\$ 780(d)$ (1994).

${ }^{106}$ See Regulation S-K, 17 C.F.R. $\$ 229.103$ (1995) (requiring issuers to include "any material pending legal proceedings, other than ordinary routine litigation incidental to the business, to which the registrant or any of its subsidiaries is a party or of which any of their property is the subject"). The issuer is not, however, obliged to disclose litigation for a claim of damages where the amount involved, exclusive of interest and costs, does not exceed $10 \%$ of the current assets of the registrant and its subsidiaries on a consolidated basis. See Regulation S-K Instructions to Item 103, 17 C.F.R. § 229.103. Furthermore, Instruction 4 to Item 103 provides:

Any material proceedings to which any director, officer or affiliate of the registrant, any owner of record or beneficially of more than five percent of any class of voting securities of the registrant, or any associate of any such director, officer, affiliate of the registrant, or security holder is a party 
minimum of four years following the IPO or where there existed a gap of eighteen months or greater between 10-K filing dates, we searched published news reports and court documents on LEXISNEXIS and Westlaw for accounts of litigation involving the firm. We gathered information on the outcome of each lawsuit from published news reports and court documents on LEXIS-NEXIS, Westlaw, and from the Class Action Reporter. ${ }^{107}$ To the extent our search procedure failed to uncover all the securities class actions related to our sample of IPOs, our sample is biased. However, the missing data most likely derive from the smaller-magnitude, lesserknown suits-suits too insignificant for firms to include in their 10-Ks and too small for newspapers or courts to report. Therefore, to the extent our sample manifests bias, it overweighs the importance of the larger IPO suits. Because the real importance of securities class actions depends on the dollar-magnitude impact on incentives of issuers and of investors ex ante, however, losing smaller-sized IPO suit data points should not affect the impact of our findings.

This Part presents several summary statistics on the IPO sample and the resulting implications for the importance of securities class actions, plaintiffs' attorneys' incentives, and the overall level of private enforcement.

\section{A. Summary Statistics}

This Section presents the following summary statistics for the IPO sample: (1) IPO and suit incidence by year; (2) resolution time period and disposition of suits; (3) offering amount distribution within the entire lawsuit IPO samples; (4) aftermarket losses of lawsuit IPOs; and (5) Standard Industry Classification (SIC) code distribution of the entire and lawsuit samples.

adverse to the registrant or any of its subsidiaries or has a material interest adverse to the registrant or any of its subsidiaries also shall be described.

Id. To the extent that a class action brought by over five percent of the shareholders counts as an action by a beneficial owner, the company must disclose the action under Item 103. See generally 2 Louis Loss \& Joel Seligman, Securities RegulaTION 648-62 (3d ed. 1989) (describing the requirements of Item 103).

107 12-15 CLASS ACTION REP. (1982-1992). Our search also involved the examination of numerous articles discussing litigation in the new-issues market. We encountered references to only two firms, both traded on pink sheets, experiencing lawsuits that were not in our sample. 


\section{IPO and Suit Incidence}

In the entire sample of 3519 IPOs, 123 of the IPOs, or about $3.5 \%$ of the sample, resulted in class-action suits. Section 11 and Rule 10b-5 actions were the predominant causes of action in these suits. The suits ranged geographically among the State of Delaware Chancery Court and thirty different federal district courts. The four federal courts with the largest numbers of suits were the Southern District of New York (twenty-three suits), the Northern District of California (seventeen suits), ${ }^{108}$ the Eastern District of Pennsylvania (ten suits), and the Central District of California (nine suits). Of the 123 IPOs which experienced a securities class-action suit in the sample, we had data on the suit-filing date for 103. The mean time period between the IPO offering date and the filing of the securities class-action suit (the "FILETIME") was 566.5 days or about 1.6 years. With a minimum of ninety days and a maximum of 1526 days (about 4.2 years), the standard deviation of the FILETIME was 352.7 days. ${ }^{109}$

A breakdown of the sample by year of offering and type of underwriting contract appears in Table 2.1.

${ }^{108}$ Eight of Alexander's nine IPO securities class actions were in the Northern District of California. See Alexander, supra note 12, at 521.

${ }^{109}$ The following table shows the incidence of IPO suits by FILETIME intervals:

\begin{tabular}{lc}
\hline \hline FILETIME Interval (Years) & IPO Lawsuits \\
\hline 0 up to 0.5 & 11 \\
0.5 up to 1 & 28 \\
1 up to 1.5 & 17 \\
1.5 up to 2 & 18 \\
2 up to 2.5 & 11 \\
2.5 up to 3 & 9 \\
3 and greater & 9 \\
\hline
\end{tabular}


TABLE 2.1: Initial Public Offering Sample By Year and Type of Underwriting Contract

\begin{tabular}{lccc}
\hline \hline Year & Best Efforts & Firm Commitments & Lawsuit Firms \\
\hline 1975 & 2 & 11 & 0 \\
1976 & 3 & 30 & 4 \\
1977 & 12 & 23 & 0 \\
1978 & 22 & 28 & 1 \\
1979 & 29 & 50 & 1 \\
1980 & 108 & 127 & 7 \\
1981 & 119 & 329 & 10 \\
1982 & 95 & 115 & 10 \\
1983 & 201 & 615 & 39 \\
1984 & 193 & 308 & 13 \\
1985 & 174 & 321 & 14 \\
1986 & 0 & 604 & 24 \\
\hline Total & 958 & 2561 & 123 \\
\hline
\end{tabular}

Table 2.1 indicates that in the late 1970 s, suits arising out of initial public offerings constituted a negligible fraction of the total number of suits in our sample. Suits involving initial public offerings rose precipitously in the early 1980s. The data, nevertheless, show that only a modest number of the total IPOs ever experienced a securities-fraud suit; IPOs which experienced a securities-fraud suit were the exception rather than the rule. ${ }^{110}$

\section{Resolution Time Period and Suit Disposition}

The vast majority of the IPO class-action suits eventually settled (ninety-six out of the 123 suits). Seven class-action suits resulted in

${ }^{110}$ Professor Romano made a similar finding in her study of derivative and securities suits. In her sample of 535 tracked public corporations, she found that 99 firms (19\%) experienced a shareholder suit for a litigation frequency of one shareholder suit every 48 years. See Romano, supra note 29, at 59. 
a pretrial resolution in favor of the IPO defendants (dismissal, denial of class certification, or summary judgment for the defendant). Three class-action IPOs ended in a trial verdict for the defendant; only one class-action IPO ended in a trial verdict for the plaintiff. Five of the class-action IPOs resulted in bankruptcy. The study failed to ascertain (due to unavailability of information) the resolution of the remaining eleven IPOs. Table 2.2 contains the result.

TABLE 2.2: IPO Securities-Fraud Class-Action Resolutions

Type of Resolution Number of Cases

Settlement

96

Pretrial Termination ${ }^{*}$

7

Defendant Prevails at Trial

Plaintiff Prevails at Trial

Issuer Bankruptcy

Unknown 11

- Includes dismissals, denial of class certification, and summary judgment for the defendant.

Of the 123 class actions, we determined the time interval between the filing of the securities class-action suit and the resolution of the suit (the RESTIME) for seventy IPOs. For settlements, we used the court order date first approving the settlement to calculate the RESTIME date. In cases where the court order date was unavailable, we relied upon the first public announcement date of the settlement instead. The mean RESTIME period was 1037.8 days or about 2.84 years. With a minimum of 154 days and a maximum of 2719 days (or about 7.45 years), the RESTIME's standard deviation was 538.3 days (or about 1.47 years). Looking at Table 2.3, the number of suits that reached resolution peaked in the 1.5- to 2-year period after the filing of suit (thirteen resolutions). 
TABLE 2.3: Time from Filing Date to Resolution of the Suit

\begin{tabular}{ll}
\hline \hline RESTIME Interval (years) & Number of Suits \\
\hline less than 0.5 & 1 \\
0.5 up to 1 & 5 \\
1 up to 1.5 & 6 \\
1.5 up to 2 & 13 \\
2 up to 2.5 & 7 \\
2.5 up to 3 & 8 \\
3 up to 3.5 & 8 \\
3.5 up to 4 & 6 \\
4 up to 4.5 & 5 \\
4.5 up to 5 & 6 \\
5 up to 5.5 & 2 \\
5.5 up to 6 & 1 \\
6 and greater & 2 \\
\hline
\end{tabular}

To examine whether defendants may settle to bring finality to an impending securities class action and save themselves the time and expense of litigating toward trial, we divided the sample into those IPO suits that (a) encountered some sort of nonsettlement pretrial termination, (b) settled, and (c) ended in a trial verdict. We present the mean RESTIMEs for each in Table 2.4.

TABLE 2.4: IPO Suit Mean RESTIME By Type of Resolution

\begin{tabular}{lcc}
\hline \hline Type of Resolution & RESTIME (Days) & RESTIME (Years) \\
\hline Pretrial Termination & 963 & 2.6 \\
Settlement & 1021 & 2.8 \\
Trial Verdict & 1213 & 3.3 \\
\hline
\end{tabular}

- Includes dismissals, denial of class certification, and summary judgment for the defendant.

These results indicate that settlement on average saves defendants almost six months worth of litigation costs, but they are 
nonetheless not settled quickly. Furthermore, because trial tends to impose much greater litigation and reputation costs on defendants, these results may understate the savings to defendants from settlement. Surprisingly, the data also show that even those class actions that are eventually dismissed or otherwise end prior to trial without settlement also take a significant amount of time. Due to the small numbers of class actions that did not end in settlement, however, these results lack statistical significance.

Of all the IPO suits in the sample, Jiffy Lube International took the shortest amount of time to settle, reaching a court-approved partial settlement agreement in under six months. ${ }^{11}$ A drivethrough automobile service chain (specializing in quick oil changes), Jiffy Lube went public in 1986. Three years later, Jiffy Lube faced several class-action suits. ${ }^{112}$ These suits alleged that Jiffy Lube's prospectus and registration statement contained, inter alia, material misstatements and omissions "concerning [Jiffy Lube's] . . . assets, earnings, and prospects." 113 Importantly, at the time of the suits, Jiffy Lube was involved in debt-restructuring negotiations with Pennzoil Co., which the class actions threatened to disrupt. ${ }^{114}$ Plaintiffs filed the class actions against Jiffy Lube on or after July 30 , 1989, four days after Pennzoil announced a preliminary debtrestructuring deal-contingent for a sixty-day implementation period $^{115}$-with Jiffy Lube. ${ }^{116}$ Some evidence exists that the

111 The named defendants included Jiffy Lube, Shearson Lehman Hutton, Inc., Alex. Brown \& Sons, Inc., Ernst \& Young, and a variety of individual defendants. All but Ernst \& Young chose to participate in the partial settlement. See Jiffy Lube Sec. Litig., [1989-1990 Transfer Binder] Fed. Sec. L. Rep. (CCH) 94,859, at 94,659 (D. Md. Jan. 2, 1990) (discussing a settlement proposal totalling $\$ 9.5$ million and demonstrating that defendants raised their initial settlement offer dramatically once the threat of restructuring emerged), vacated and remanded, In re Jiffy Lube Sec. Litig., 927 F.2d 155 (4th Cir 1991).

112 These suits were eventually consolidated in the U.S. District Court for the District of Maryland. See Jiffy Lube, [1989-1990 Transfer Binder] Fed. Sec. L. Rep. (CCH) at 94,657-58.

${ }^{113}$ Jiffy Lube, 927 F.2d at 157.

114 See Jiffy Lube Pact Is Delayed, WALL ST. J., Sept. 25, 1989, at A2 (quoting a spokeswoman for Jiffy Lube as saying: "Pennzoil has advised the company that it will not close until there is a resolution [to the class-action lawsuits]").

${ }^{115}$ During this period, the deal was contingent on gaining the approval of senior lender committees and on the completion of complex agreements among parties as well as applicable regulatory filings. See Jiffy Lube Announces Agreement with Creditors and Pennzoil, PR Newswire, July 26, 1989, available in Westlaw, Wireplus database.

${ }^{116}$ See Jiffy Lube, [1989-1990 Transfer Binder] Fed. Sec. L. Rep. (CCH) at 94,658 ("Pennzoil had announced an agreement with JLI [Jiffy Lube International] whereby they would convert certain JLI subordinated debentures into common stock 
plaintiffs obtained a much quicker and larger settlement award as a result of the pending Pennzoil debt restructuring. The need to close the Pennzoil deal, combined with pressure from the Pennzoil board of directors, led Jiffy Lube to raise their initial settlement offer of $\$ 2.5$ million to $\$ 9.5$ million and agree to a settlement in principle as early as October 13, 1989-less than three months after the filing of the securities class-action suit. ${ }^{117}$ We did not test whether companies in the midst of mergers, takeovers, or debt restructuring were sued more frequently than other firms. Plaintiffs' attorneys, however, may sue these companies because the threat of litigation might stall or destroy such deals. To avoid this outcome, companies may pay plaintiffs' attorneys "greenmail" settlements to end the litigation. ${ }^{118}$

For the eighty-one IPOs in which we learned the settlement amount, the average settlement award was $\$ 5.3$ million in 1993 dollars. ${ }^{119}$ This ranged from a low of $\$ 7283$ to a high of $\$ 44.9$ million in 1993 dollars. Professor Grundfest presents an interesting test of the merits of securities class actions. He argues that suits which settle above the defendants' litigation costs are merit based because defendants would not pay over their litigation costs to avoid a frivolous lawsuit. Conversely, suits where the settlement falls below the defendants' litigation costs may well be frivolous suits. ${ }^{120}$ The defendants' expected litigation costs may, however, vary by suit. In addition, defendants may pay more than their expected cost of litigation to rid themselves of frivolous suits that cause great harm to their reputation or disrupt their business prospects. Nevertheless, if we take $\$ 2$ million as the cut-off amount of the defendants' litigation expenses-an amount within the range cited by Grundfest ${ }^{121}$-we find in our data sample the following:

permitting Pennzoil to purchase an $80 \%$ stake in JLI."). Jiffy Lube announced the preliminary agreement on July 26, 1989. See Jiffy Lube Announces Agreement with Creditors and Pennzoil, supra note 115.

${ }^{117}$ See Jiffy Lube, [1989-1990 Transfer Binder] Fed. Sec. L. Rep. (CCH) at 94,660.

${ }^{118}$ We leave these tests for another article.

${ }^{119}$ The average attorney's fees paid out were $\$ 1.97$ million in 1993 dollars (39 cases); these fees represented $26.9 \%$ of the settlement award. This is consistent with Alexander's finding that attorneys received on average $25 \%$ of the settlement amount as their fee. See Alexander, supra note 12, at 541. The average class-action plaintiffs' expenses paid were $\$ 290,000$ in 1993 dollars (29 cases), representing $4.3 \%$ of the settlement award.

${ }^{120}$ See Grundfest, supra note 60, at 741-43.

${ }^{123}$ See id. at 742. 
$54.1 \%$ of the settlements were for $\$ 2$ million or below and $45.9 \%$ were for more than $\$ 2$ million. Thus, according to this crude test, at least over half the securities class-action settlements would qualify as possible frivolous suits.

Most importantly, the data confirmed that IPO securities-fraud suits almost always settle. Only four in the sample of 123 IPO lawsuits ended in definite trial verdicts. Therefore, for the effect of securities-fraud class actions on the ex ante incentives of participants in the IPO process, more significant than the merits at trial was the impact of merits on settlement awards.

\section{Offering Amount}

Offering amount ${ }^{122}$ data exist for 3290 of the 3519 IPOs in the sample. The mean offering amount in 1993 dollars was $\$ 16.6$ million. The minimum offering amount was $\$ 83,000$, while the maximum was $\$ 1.569$ billion with a standard deviation of $\$ 54.5$ million in 1993 dollars. Although IPOs with large offering size make headlines, ${ }^{123}$ the smaller IPOs predominate both in number and in total dollar magnitude. Looking at Table 2.5, the majority of IPOs had offering amounts under $\$ 10$ million. Over ten percent of the IPOs, in fact, had offering amounts below $\$ 2$ million. The median offering was $\$ 6.9$ million in 1993 dollars; furthermore, almost ninety percent of the sample IPOs had offering amounts below $\$ 30$ million in 1993 dollars. In terms of dollar magnitude, offerings below $\$ 30$ million in 1993 dollars accounted for fifty-two percent of the dollar volume of IPOs in our sample. ${ }^{124}$ Far more important to capital formation, therefore, is the impact of the threat of securities class actions on these smaller offerings.

Compared to the total IPO sample, the offering amount distribution of the lawsuit IPOs was skewed considerably upward.

${ }^{122}$ Offering amount is the offering price times the number of shares actually sold in the offering. Most of the 229 dropped observations were removed because we could not determine the number of shares sold in the offering.

${ }^{123}$ For example, when Netscape went public this year, it attracted considerable attention from institutional investors to computer enthusiasts. The Wall Street Journal covered the offering extensively, following the first-day aftermarket price as it almost tripled and then fell to a low which still more than doubled the initial offering price. See Molly Baker, Technology Investors Fall Head over Heels for Their New Love: Little Stock Called Netscape Is Lofted to the Heavens in a Frenzy of Trading, WALL ST. J., Aug. 10,1995 , at A1.

${ }^{124}$ This result is in part driven by the presence of a few outlier IPOs with offering amounts in the billions of dollars in our sample. 
We obtained offering amount data for 122 of the lawsuit IPOs. The mean offering amount for the lawsuit IPOs was $\$ 39.3$ million in 1993 dollars. The lawsuit IPO minimum offering amount was $\$ 1.45$ million and the maximum was $\$ 217.8$ million, with a standard deviation of $\$ 47.5$ million in 1993 dollars. Table 2.5 contain these results.

TABLE 2.5: Suit Frequency By Offering Size

\begin{tabular}{lccc}
\hline \hline Interval ( $\$$ million) & Number of Firms & Suits & Rate \\
\hline less than 1.79 & 329 & 1 & $0.30 \%$ \\
1.79 to 2.96 & 329 & 2 & $0.61 \%$ \\
2.97 to 3.97 & 328 & 1 & $0.30 \%$ \\
3.98 to 5.12 & 330 & 3 & $0.91 \%$ \\
5.13 to 6.71 & 329 & .7 & $2.12 \%$ \\
6.72 to 9.27 & 329 & 10 & $3.04 \%$ \\
9.28 to 14.24 & 329 & 16 & $4.86 \%$ \\
14.25 to 21.54 & 329 & 22 & $6.69 \%$ \\
21.55 to 38.58 & 330 & 20 & $6.06 \%$ \\
38.59 to 1568.93 & 328 & 40 & $12.20 \%$ \\
\hline All firms & 3290 & 122 & $3.49 \%$ \\
\hline
\end{tabular}

We sorted the IPO sample by the size of the offering into ten portfolios by the amount of money raised in the IPO. We calculated offering size intervals in 1993 dollars. We could not obtain the actual number of shares sold in the offering, and therefore the offering amount was unavailable for 229 firms, including one firm experiencing a lawsuit arising out of the offering process. Differences in interval size result from multiple firms with the same offering size.

The most striking result from this summary data is that smaller sized offerings hardly ever experience a securities-fraud suit. The relationship between size and suit incidence is statistically significant at the $0.5 \%$ confidence level $\left(\chi^{2}=120.8\right.$; probability $\left.<0.005\right)$. Of the 329 IPOs within the less than $\$ 1.79$ million bracket, only one firmRoltec Corporation-faced a class-action suit. Roltec went public on October 12; 1983, with an issue price of $\$ 0.25$ per share for 4 million shares. ${ }^{125}$ The second smallest offering to experience a

${ }^{125}$ The Roltec Corporation offering amount in 1993 dollars was $\$ 1.45$ million. 
ence a securities-fraud class action was Cymaticolor, which went public on January 13,1981, selling 300,000 shares at five dollars per share. ${ }^{126}$ On June 28, 1984, the SEC charged Cymaticolor with making false and misleading statements, including disclosing overoptimistic reports about its "Cymaticolor process" of color printing during its IPO and unlawfully manipulating the price of its shares once aftermarket trading had commenced. ${ }^{127}$ Plaintiffs' attorneys soon followed alleging similar charges in their own private securities class action less than one month later. Cymaticolor eventually settled, paying out $\$ 200,000$ of which $\$ 60,000$ went to attorneys' fees. ${ }^{128}$

Several experts have commented on the threat of securities classaction suits against small companies seeking to go public. ${ }^{129}$ The data for 1975 to 1986 , however, seem to contradict this conventional wisdom. Although firms such as Roltec and Cymaticolor confronted a securities-fraud class action, the vast majority of similarly sized IPOs did not. As discussed below, this phenomenon is partly explained by the fact that plaintiffs' attorneys' incentives drive the decision to file suit. Whether enforcement or strike-suit motivated, plaintiffs' attorneys will only file suit where their expected fee award exceeds their fixed costs of litigation. ${ }^{130}$

\section{Aftermarket Losses}

To examine the relationship between aftermarket loss and suit incidence, we partitioned the empirical IPO sample according to the three-year aftermarket loss experienced by the IPOs. The potential damages award that a successful securities class-action plaintiff may

Our data search failed to uncover information on the outcome of the Roltec securities-fraud class-action litigation.

126 The Cymaticolor offering amount in 1993 dollars was $\$ 2.38$ million.

${ }^{127}$ See SEC Says Cymaticolor, 2 Officers, 5 Others Manipulated Stock, WALL ST. J., June 28,1984 , at 2.

${ }^{128}$ Cymaticolor last traded at one cent per share on January 1990. Today, no liquid market for its shares exists. See Andrew Leckey, On Personal Finance: Investment Shoe Still Fits L.A. Gear, CHI. TrIB., Nov. 19, 1990, § 4 (Business), at 3. The SEC suit settled in 1986 with Joel Green, the ex-president of Cymaticolor, agreeing not to act as a director or officer of an SEC-reporting company and to pay $\$ 100,000$ into a settlement fund for private plaintiffs. See SEC v. Cymaticolor Corp., No. 84 Civ. 4508, 1986 WL 73206, at *1 (S.D.N.Y. April 1, 1986).

${ }^{129}$ See Fletcher, supra note 22, at 493-99 \& nn.1-4.

130 Alexander finds a similar result in her sample of 17 computer IPOs from 1983. Of those IPOs under $\$ 20$ million, no issuers experienced a securities class action. See Alexander, supra note 12, at 510-13. 
obtain depends on this aftermarket loss measure. For example, under section 11 the plaintiff receives the difference between the purchase price (or the offering price, if lower) and either (1) the value of the security at the time of the suit filing, (2) the resale price of the security if resold prior to the suit, or (3) the resale price of the security if resold after the filing of suit if the resale price is higher than at the suit filing. ${ }^{131}$ This study utilized the three-year aftermarket loss because the statute of limitations for federal securities actions runs until the three-year mark after the offering. This methodology, however, lacks precision for three reasons. First, prior to the Supreme Court's decision in Lampf, Pleva, Lipkind, Prupis $\mathcal{E}$ Petigrow v. Gilbertson, ${ }^{132}$ Rule $10 \mathrm{~b}-5$ actions could, depending on the relevant state statute of limitations, run shorter or longer. ${ }^{133}$ Second, for those IPOs which were the subjects of lawsuits within the three-year period after the offering date (for example, at the one-year mark), using the three-year low may in fact incorporate any changes in the IPO stock price that occurred after the filing of suit-changes irrelevant to the decision to file the suit. Finally, the aftermarket loss measure may overstate the potential damages award to the extent that the defendant can prove alternative causes for the decline in the stock price. ${ }^{134}$ Nevertheless, the three-year aftermarket loss provides a highly correlated proxy for the maximum amount of damages available to a securities plaintiff. ${ }^{135}$ As such, the three-year aftermarket loss allows us to

${ }^{131}$ See Securities Act $\S 11(e), 15$ U.S.C. $\S 77 k(e)$ (1994). Defendants are able to reduce this damage measure by showing an alternative cause for the stock price decline. See id. In Rule 10b-5, plaintiffs receive an "out-of-pocket" fraud measure. This typically gives the plaintiff the difference between the price they paid for the security and the "true value" of the security at the time of purchase. The "true value" is the value of the security had no securities-fraud violation occurred. See Janet C. Alexander, The Value of Bad News in Securities Class Actions, 41 UCLA L. REv. 1421, 1428-29 \& nn.22-24 (1994). For purposes of this Article, the distinctions between section 11 and Rule 10b-5 damages are ignored.

132501 U.S. 350 (1991).

139 For example, prior to $L a m p f$, the statute of limitations for Rule $10 \mathrm{~b}-5$ actions in Oregon corresponded to Oregon's two-year statute of limitations for fraud claims. See id. at 353.

${ }^{134}$ See Securities Act $\$ 11(e), 15$ U.S.C. $\$ 77 \mathrm{k}(\mathrm{e})$. Seligman criticizes several recent securities class-action studies for not adjusting aftermarket losses to account for other causes of the decline in the reporting company's stock price. See Seligman, supra note 18 , at $450-53$.

135 Although Seligman's point is valid to the extent aftermarket losses are correlated with the true potential damage measure, our results still show a tendency for securities class actions to cluster at the high end of the potential damages award distribution. 
examine differences in the distribution of the entire sample IPOs versus the lawsuit IPOs.

The partition divides the sample into ten-million-dollar aftermarket loss intervals below in Table 2.6.

TABLE 2.6: Aftermarket Losses and Suit Incidence for IPOs from 1975-1986

\begin{tabular}{lccc}
\hline $\begin{array}{l}\text { CRSP Aftermarket } \\
\text { Losses (\$ million) }\end{array}$ & $\begin{array}{l}\text { Number of } \\
\text { CRSP Listed } \\
\text { IPOs }\end{array}$ & $\begin{array}{l}\text { Number of IPOs } \\
\text { Experiencing a } \\
\text { Class Action }\end{array}$ & $\begin{array}{l}\text { Percentage of IPOs } \\
\text { Experiencing a Suit }\end{array}$ \\
\hline less than 5 & 1619 & 24 & $1.48 \%$ \\
5 up to 10 & 374 & 26 & $6.95 \%$ \\
10 up to 20 & 205 & 18 & $8.78 \%$ \\
20 up to 30 & 92 & 13 & $14.13 \%$ \\
30 up to 40 & 32 & 5 & $15.63 \%$ \\
40 up to 50 & 15 & 4 & $26.67 \%$ \\
50 up to 100 & 29 & 8 & $27.58 \%$ \\
100 and greater & 14 & 6 & $42.86 \%$ \\
\hline
\end{tabular}

We partitioned suit frequency by the level of aftermarket losses suffered by purchasers at the time of the IPO. We calculated losses as the difference between the offering price and the low price in the first three years after the IPO multiplied by the number of shares offered. We adjusted the low price to account for the effect of dividends and stock splits. We computed losses for firms with daily returns available from the University of Chicago Graduate School of Business's Center for Research in Securities Prices (CRSP).

We omitted firms if the first day of listing on the GRSP tape was two or more days after the IPO or if there were five or more trading days in the first three years with missing returns data. Firms were analyzed through the first three years of being listed on or until the date of delisting from GRSP. We had no way of adjusting the losses to account for the effect of secondary offerings.

The data in Table 2.6 show that most IPOs did not suffer aftermarket losses in excess of five million dollars. This result was statistically significant at the $0.5 \%$ level $\left(\chi^{2}=183.4\right.$; probability $<0.005$ ). Of the 2380 IPOs for which aftermarket loss data exist, only 761, or thirty-two percent, experienced an aftermarket loss of greater than five million dollars in value. Similarly, class-action incidence was more skewed toward those firms experiencing lower levels of aftermarket losses. Of the 104 lawsuit IPOs for which 
aftermarket loss data exist, almost a quarter had less than $\$ 5$ million in aftermarket losses. On a percentage basis, however, the probability of a class-action suit increases dramatically as the aftermarket loss increases. IPOs that experienced an aftermarket loss of less than five million dollars were sued only $1.48 \%$ of the time. ${ }^{136}$ Contrast this with IPOs experiencing an aftermarket loss of greater than $\$ 100$ million, which were sued $42.86 \%$ of the time.

The data from the partition of IPO suits by aftermarket losses are consistent with the offering amount data in Part II.A.3 above. Suits seem to occur more frequently as the chances increase of plaintiffs' attorneys recovering an expected fee award larger than their fixed costs of litigation. On the other hand, not all IPOs within the higher aftermarket loss categories were sued and, similarly, not all IPOs with lower aftermarket losses escaped suit. For example, in our sample, Command Credit Corporation experienced an aftermarket loss of $\$ 739.3$ million, representing 99.9\% of its IPO offering amount, and Datatrak experienced a similarly large drop of $\$ 507$ million or $92.2 \%$ of its IPO offering amount. Yet neither Command Credit Corporation nor Datatrak ever faced an IPO securities-fraud suit. Nevertheless, the stark difference between the different aftermarket loss categories does indicate that regardless of merit or strike-suit motivations, plaintiffs' attorneys tend to focus their attention only on IPOs which promise at least some minimum level of expected damages.

\section{Standard Industry Classification Code}

Looking at the summary statistics for the IPOs and class-action suits by Standard Industry Classification (SIC) code, the data, contained in Table 2.7, demonstrate at least a rough correlation between the SIC codes and the rate of IPO suit filings. The twodigit SICs with the five largest number of IPOs include: Business Enterprises (SIC 73: 445 IPOs with eleven class-action IPOs-2.5\% incidence), Electronic \& Other Electronic Equipment (SIC 36: 315 IPOs with seven class-action IPOs-2.2\% incidence), Industrial Machinery \& Equipment (SIC 35: 296 IPOs with twenty-four classaction IPOs-8.1\% incidence), and Oil \& Gas Extraction (SIC 13: 253 IPOs with four class-action IPOs-1.5\% incidence).

${ }^{136}$ In fact, IPOs that suffered an aftermarket loss of less than $\$ 1$ million were sued only $0.7 \%$ of the time. 
TABLE 2.7: Two-Digit SIC Code Breakdown

\begin{tabular}{|c|c|c|c|c|c|c|c|}
\hline SIC & IPOs & Suits & Suits/IPO & SIC & IPOs & Suits & Suits/IPO \\
\hline- & 4 & 0 & $0.0 \%$ & 46 & 1 & 0 & $0.0 \%$ \\
\hline 1 & 9 & 1 & $11.1 \%$ & 47 & 15 & 0 & $0.0 \%$ \\
\hline 2 & 16 & 0 & $0.0 \%$ & 48 & 102 & 1 & $1.0 \%$ \\
\hline 7 & 7 & 1 & $14.3 \%$ & 49 & 43 & 1 & $2.3 \%$ \\
\hline 8 & 2 & 0 & $0.0 \%$ & 50 & 120 & 2 & $1.7 \%$ \\
\hline 9 & 2 & 0 & $0.0 \%$ & 51 & 64 & 4 & $6.3 \%$ \\
\hline 10 & 44 & 0 & $0.0 \%$ & 52 & 5 & 0 & $0.0 \%$ \\
\hline 11 & 2 & 0 & $0.0 \%$ & 53 & 17 & 1 & $5.9 \%$ \\
\hline 12 & 5 & 0 & $0.0 \%$ & 54 & 25 & 1 & $4.0 \%$ \\
\hline 13 & 253 & 4 & $1.6 \%$ & 55 & 6 & 0 & $0.0 \%$ \\
\hline 14 & 4 & 0 & $0.0 \%$ & 56 & 32 & 4 & $12.5 \%$ \\
\hline 15 & 18 & 0 & $0.0 \%$ & 57 & 32 & 6 & $18.8 \%$ \\
\hline 16 & 11 & 0 & $0.0 \%$ & 58 & 92 & 4 & $4.3 \%$ \\
\hline 17 & 6 & 1 & $16.7 \%$ & 59 & 72 & 4 & $5.6 \%$ \\
\hline 20 & 45 & 1 & $2.2 \%$ & 60 & 236 & 0 & $0.0 \%$ \\
\hline 21 & 2 & 0 & $0.0 \%$ & 61 & 94 & 2 & $2.1 \%$ \\
\hline 22 & 9 & 2 & $22.2 \%$ & 62 & 41 & 2 & $4.9 \%$ \\
\hline 23 & 17 & 2 & $11.8 \%$ & 63 & 60 & 3 & $5.0 \%$ \\
\hline 24 & 12 & 0 & $0.0 \%$ & 64 & 8 & 0 & $0.0 \%$ \\
\hline 25 & 9 & 0 & $0.0 \%$ & 65 & 27 & 0 & $0.0 \%$ \\
\hline 26 & 14 & 0 & $0.0 \%$ & 66 & 2 & 0 & $0.0 \%$ \\
\hline 27 & 36 & 0 & $0.0 \%$ & 67 & 179 & 1 & $0.6 \%$ \\
\hline 28 & 134 & 1 & $0.7 \%$ & 68 & 1 & 0 & $0.0 \%$ \\
\hline 29 & 12 & 0 & $0.0 \%$ & 70 & 16 & 0 & $0.0 \%$ \\
\hline 30 & 29 & 1 & $3.4 \%$ & 72 & 13 & 0 & $0.0 \%$ \\
\hline 31 & 6 & 0 & $0.0 \%$ & 73 & 445 & 11 & $2.5 \%$ \\
\hline 32 & 9 & 0 & $0.0 \%$ & 75 & 8 & 1 & $12.5 \%$ \\
\hline 33 & 21 & 0 & $0.0 \%$ & 76 & 5 & 0 & $0.0 \%$ \\
\hline 34 & 51 & 0 & $0.0 \%$ & 77 & 5 & 0 & $0.0 \%$ \\
\hline 35 & 296 & 24 & $8.1 \%$ & 78 & 60 & 5 & $8.3 \%$ \\
\hline 36 & 315 & 7 & $2.2 \%$ & 79 & 30 & 2 & $6.7 \%$ \\
\hline 37 & 39 & 2 & $5.1 \%$ & 80 & 124 & 6 & $4.8 \%$ \\
\hline 38 & 241 & 6 & $2.5 \%$ & 81 & 1 & 0 & $0.0 \%$ \\
\hline 39 & 46 & 2 & $4.3 \%$ & 82 & 13 & 1 & $7.7 \%$ \\
\hline 40 & 3 & 0 & $0.0 \%$ & 83 & 4 & 0 & $0.0 \%$ \\
\hline 41 & 2 & 0 & $0.0 \%$ & 84 & 1 & 0 & $0.0 \%$ \\
\hline 42 & 18 & 0 & $0.0 \%$ & 87 & 60 & 3 & $5.0 \%$ \\
\hline 44 & 5 & 1 & $20.0 \%$ & 89 & 22 & 0 & $0.0 \%$ \\
\hline 45 & 48 & 2 & $4.2 \%$ & & & & \\
\hline
\end{tabular}

- No SIC code recorded. 
The two-digit SIC code level of generality may, however, ignore some bunching within each two-digit SIC code category. For example, within SIC 73 is SIC 731 (Advertising), which experienced no IPO securities class-action suits, and SIC 737 (Computer and Data Services), which experienced a suit incidence of $3.75 \%$. However, the test of differences among all three-digit SIC groups lacks statistical power due to the small number of IPOs in many of the three-digit SIC code categories. As a rough test, then, we selected only those three-digit SIC codes which had over fifty IPOs. This, in fact, may bias our results toward not finding a correlation between SIC codes and suit incidence because one would expect the lowest incidence of suits to occur within the SIC codes with the lowest number of IPOs due to the fixed costs plaintiffs' attorneys must incur to become an expert in any given industry. ${ }^{137}$ It is financially more rewarding, for example, to become an expert in the type of risks and potential omissions in the computer industry where there are numerous IPOs than to gain expertise in the veterinary services industry where there was only one IPO in our sample.

A comparison of the three-digit SIC groups containing greater than fifty IPOs reveals a difference in suit incidence between groups. Table 2.8 shows that the incidence levels range from a high of ten percent (229 IPOs with twenty-three class-action IPOs) in the Computer \& Office Equipment three-digit SIC group (the same group on which Alexander focused her empirical study $)^{138}$ to a low of zero percent (ninety-one IPOs with no class-action IPOs) in the Crude Petroleum and Natural Gas three-digit SIC group. ${ }^{139}$ These differences, furthermore, are statistically significant at the $0.5 \%$ level $\left(\chi^{2}=41.1 ;\right.$ probability $\left.<0.005\right)$.

${ }^{137}$ See infra part II.B.2 (discussing the incentives of plaintiffs' attorneys).

138 The trend of securities class-action suits within the high-technology computer area continues today. See Carolyn Lochhead, Shareholder Lawsuits Defended By Lawyer at House Hearing, S.F. CHRON., Jan. 20, 1995, at A4 (reporting that 25\% of hightechnology companies had a securities class-action suit filed against them).

139 Note, however, that because this is essentially a rough univariate comparison, several other factors may account for this difference. For example, some SIC codes may have experienced extremely good stock price performance, while other SIC codes may have experienced extremely bad price performance. 
TABLE 2.8: Three-Digit SIC Code Breakdown for SIC Code Groups with Greater than Fifty IPOs.

\begin{tabular}{lccc}
\hline \hline SIC Code & & & $\begin{array}{c}\text { Suit } \\
\text { Incidence }\end{array}$ \\
\hline 131 (Crude Petroleum and Nat. Gas) & 91 & 0 & $0.0 \%$ \\
138 (Oil and Gas Field Services) & 158 & 4 & $2.5 \%$ \\
283 (Drugs) & 87 & 1 & $1.1 \%$ \\
357 (Computer and Office Equipment) & 229 & 23 & $10.0 \%$ \\
366 (Communications Equipment) & 126 & 2 & $1.6 \%$ \\
367 (Electronic Comp. and Access) & 114 & 3 & $2.6 \%$ \\
382 (Measuring and Controlling Devices) & 71 & 2 & $2.8 \%$ \\
384 (Medical Instruments and Supplies) & 118 & 4 & $3.4 \%$ \\
581 (Eating and Drinking Places) & 92 & 4 & $4.3 \%$ \\
679 (Miscellaneous Investing) & 106 & 1 & $0.9 \%$ \\
737 (Computer and Data Services) & 240 & 9 & $3.8 \%$ \\
739 (Business Services) & 159 & 2 & $1.3 \%$ \\
\hline
\end{tabular}

In particular, two SIC code groups with relatively high levels of R\&D-the computer-related and drugs SIC code groupsexperienced widely divergent levels of securities class actions. As noted above, the computer SIC code group had a ten-percent incidence of suits. The drugs SIC code, on the other hand, had only a 1.1-percent incidence of suits. Out of the eighty-seven IPOs in the drugs SIC code, only one issuer, Techamerica Group, Inc., experienced a suit. A developer and manufacturer of biological, pharmaceutical, and diagnostic products primarily for the animal health-care industry, Techamerica announced on January 8,1982 that it faced a $\$ 9.5$ million class-action suit for misstatements of fact and omissions in its August 6, 1981 IPO prospectus. It eventually settled two years later on May 10, 1984 for $\$ 1.3$ million. High levels of R\&D normally correlate with a greater number of risk factors and uncertainty in the IPO. Some factor either in addition to or other than high-technology, therefore, drives the incentives of plaintiffs' attorneys. 


\section{B. Implications}

Three implications follow from our summary statistics. First, the number of securities class actions as a percentage of the total number of IPOs is modest. Second, plaintiffs' attorneys' incentives drive the initiation of securities class actions. Finally, because private enforcement neglects smaller IPOs and IPOs in several different SIC codes, the SEC may wish to increase public enforcement efforts targeted at these deficient areas. The Sections below discuss each of these implications in further detail.

\section{Low Frequency of IPO Suits}

Only $3.5 \%$ of the IPOs in our sample had ever experienced an IPO suit. Although most issuers need not worry excessively about facing a lawsuit, ${ }^{140}$ this does not mean that securities-fraud class actions do not impact the incentives of issuers ex ante. The large amount of many securities class-action settlements ensures that all issuers ex ante will take into account the expected cost of such suits. For example, the average settlement amount per suit was $\$ 5.3$ million in 1993 dollars. Because the incidence of suits was $3.5 \%$ and the settlement rate was $75.6 \%$, all IPOs in our sample ex ante faced an expected litigation liability of $\$ 145,000$ in 1993 dollars. ${ }^{141}$ Furthermore, this may understate the actual expected litigation liability that firms in certain SIC groupings face. IPO securities litigation, for example, placed a much greater burden on computer IPOs.

140 William S. Lerach makes a similar claim that the number of securities-fraud class actions has not risen dramatically. In fact, Lerach presents data that as a proportion of volume trading and number of offerings, the frequency of securities class actions has declined. See Lerach, supra note 14, at 14-17. Importantly, the number of securities class actions filed does not equal the number of companies actually sued. Often, several class actions are filed concurrently for the same cause of action against the same company. Looking at the number of class-action filings, therefore, overstates the number of companies experiencing such suits. See, e.g., Private Litigation Under the Federal Securities Laws, Hearings Before the Subcomm. on Securities of the Senate Comm. on Banking, Housing, and Urban Affairs, 103d Cong., 1st Sess. 141, 777 (1993) (statement of James M. Newman, Publisher \& Editor, Securities Class Action Alert) (noting that "fraud results in multiple case filings and thus increases the number of cases filed but not necessarily the number of companies sued"); see also John C. Coffee, Jr., Securities Class Actions: Myth, Reality and Reform, N.Y. L.J., July 28, 1994, at 5 (arguing against the myth that there has been "an epidemic of securities litigation").

${ }_{141}$ Note that because this amount does not include legal defense costs, this underestimates the expected litigation liability cost. 
In addition, under both enforcement and strike-suit theories, parties adjust their behavior to the threat of a securities-fraud suit. Under enforcement theories, issuers choose to release less misleading information than they would in a world without securities-fraud liability. ${ }^{142}$ Under strike-suit theories, issuers and underwriters may choose to underprice their securities to reduce the possibility of a frivolous securities-fraud action. ${ }^{143}$ These adjustments result in a lower equilibrium level of securities-fraud actions; however, the threat of a securities suit's impact through these adjustments may be considerable. The low frequency of suits, therefore, does not mean that securities-fraud suits are unimportant.

\section{Plaintiffs' Attorneys' Incentives}

The summary statistics provide some support for the argument that plaintiffs' attorneys' incentives drive the filing of securitiesfraud class actions against IPOs. As reported above, most suits tend to focus on IPOs with large offering sizes and which experience large aftermarket losses. Securities plaintiffs' attorneys often face considerable fixed costs in pursuing an IPO class-action suit-costs that do not vary from IPO suit to IPO suit but that are incurred by the attorneys in all such actions. Plaintiffs' attorneys, for example, must coordinate the class action, conduct depositions, file motions, and learn about the individual issuer company and its industry. ${ }^{144}$ Because such costs do not vary between different IPO suits, plaintiffs' attorneys will choose to file suit only against those issuers of IPOs with potential damages awards larger than the fixed costs of pursuing a securities class action.

To the extent that plaintiffs' attorneys cannot determine the merits of a case before investing in the fixed costs of litigation, plaintiffs' attorneys will file suit against both culpable and nonculpable IPO issuing teams, so long as the potential damages award justifies the suit. This tends to support the strike-suit theory. If plaintiffs' attorneys know of the merits before they invest the fixed

${ }^{142}$ Alternatively, issuers may disclose more information than cost-justified to avoid litigation. See Letter from Roberta Romano, Professor of Law, Yale Law School, to Stephen Choi 2 (Sept. 22, 1995) (on file with authors) [hereinafter Romano Letter].

113 See supra note 36 and accompanying text.

114 Alexander argues similarly that expected fees in the range of $\$ 1.25$ million are necessary to induce a plaintiffs' attorney to file suit. See Alexander, supra note 12, at $513 \mathrm{n} .46$ ( $" \mathrm{Fees}$ in this range are necessary to support contingent-fee litigation of the size, complexity, duration, and out-of-pocket expense involved in securities class actions."). 
costs of litigation, however, such costs are not necessarily inconsistent with the enforcement theory. Plaintiffs' attorneys may simply file suit against those IPOs when there exists both the presence of ex ante fraud and a large enough potential damages award at least to cover their fixed costs. In either case, our findings indicate that private securities suits generally ignore the smaller IPOs. Even for adherents of the enforcement theory, this suggests that the securities laws leave open a large vacuum unpoliced by private plaintiffs. Public enforcement, therefore, may be needed to encourage compliance with the securities laws among small IPO issuers.

Similarly, the IPO issuer's industry weighs heavily in the plaintiffs' attorneys' decision with respect to filing suit. Plaintiffs' attorneys must expend a certain amount of one-time costs acquiring sufficient knowledge about a particular industry to enable them to generate a complaint listing the various risk factors and potential omissions relevant to that particular industry. For example, while the computer IPO issuers of the late 1980s should have foreseen the computer price wars of the early 1990s, such information would be irrelevant to other securities-fraud class actions and therefore worthless for a plaintiffs' attorney uninterested in the computer industry. Plaintiffs' attorneys may spread these fixed costs of acquiring expertise by focusing their attention on one industry. Furthermore, some industries may have greater numbers of IPOs due to new products, new markets, or barriers-to-entry for established firms. Plaintiffs' attorneys may choose to specialize in industries with greater numbers of IPOs to increase the frequency of suits over which they are able to spread the fixed costs of specialization. ${ }^{145}$

There exist several other reasons for concentrating on one particular industry. First, defendants in certain industries may be more prone to a securities class action and therefore represent more "juicy" settlement targets. Consumer retail industry board members, for example, may have more ties to other boards than other industry board members and, therefore, have more fear about damage to their business reputation from a public lawsuit. Second, certain industry groups may inherently find it much harder to quantify risks and, therefore, may invite more fraudulent omission

${ }^{145}$ Cf. Christopher B. Barry et al., The Role of Venture Capital in the Creation of Public Companies, 27 J. FIN. ECON. 447, 449-50, 457 (1990) (finding evidence that venture capitalists tend to specialize in certain industries). 
claims. ${ }^{146}$ Finally, should a particular law firm or underwriter prove to be litigation prone, we would expect to see shareholder lawsuits clustering along industry lines, because attorneys and underwriters often develop a clientele in one industrial group. ${ }^{147}$ These alternative reasons are consistent with the claim that plaintiffs' attorneys' incentives drive securities class actions. Because the expected settlement award is higher, plaintiffs' attorneys will value pursuing litigation against defendants more vulnerable to litigation. Furthermore, to the extent that none of the reasons depend on the merits of the defendants' information disclosure, these alternative reasons bolster the strike-suit hypothesis.

\section{SEC Enforcement}

The importance of plaintiffs' attorneys' incentives in filing a securities-fraud class action necessarily results in gaps in the level of private enforcement of the securities laws. Although the current "private attorney general"148 system saves public enforcement resources, ${ }^{149}$ it lacks universal coverage. Less than one percent of IPOs experiencing aftermarket losses of less than one million dollars were sued..$^{150}$ Of the 329 IPOs with an offering size less than $\$ 1.79$ million, only one was targeted for a class action. ${ }^{151}$ Simi-

${ }^{146}$ For example, a new pharmaceutical start-up may have a much harder time quantifying the potential risks facing its technologically revolutionary drug products than a new textile company employing well-known and tested manufacturing technologies.

${ }^{147}$ For example, underwriter A may specialize in computer IPOs. Underwriter A may also have a reputation among securities plaintiff' attorneys as being a pushover in litigation. Therefore, plaintiffs' attorneys may consistently seek to sue underwriter $A$ and, therefore, indirectly choose to sue the computer IPOs.

${ }^{148}$ See, e.g., Mitsubishi Motors Corp. v. Soler Chrysler-Plymouth, Inc., 723 F.2d 155, 168 (1st Cir. 1983) (citing American Safety Equip. Corp. v. J.P. Maguire \& Co., 391 F.2d 821, 826 (2d Cir. 1968)), aff'd in part and rev'd in part, 473 U.S. 614 (1985).

${ }^{149}$ Several commentators have written in support of private enforcement of the securities laws. See, e.g., 5A ARNold S. JACOBS, LITIGATION AND PRACTICE UNDER RULE 10B-5, § 8.01 (2d ed. 1992) ("Private actions are the most effective way to police $10 \mathrm{~b}-5$ breaches and provide the deterrent element so essential in securities transactions." (footnote omitted)).

${ }^{150}$ Note that this contradicts the conventional wisdom that strike-suit plaintiffs' attorneys target small companies that experience relatively larger swings in their share prices. See Brent Bowers \& Udayan Gupta, Shareholder Suits Beset More Small Companies, WALl ST. J., Mar. 9, 1994, at B1.

${ }^{151}$ See supra part II.A.3 (reporting offering amount summary data); see also Grundfest, supra note 60, at $734 \&$ n.46 (noting that plaintiffs' counsel are more likely to file claims "with greater probabilities of large recoveries" and that sharp price declines are significant in identifying potential claims). 
larly, the Crude Petroleum and Natural Gas and Drugs SIC code industries together had 178 IPOs but only one suit in our sample. Although univariate summary statistics, these data provide strong evidence that smaller sized IPOs, IPOs which experience relatively small aftermarket losses, and IPOs in certain industry groups are not adequately policed through the actions of plaintiffs' attorneys. ${ }^{152}$ Regardless of whether the enforcement theory or strikesuit theory more accurately describes the dynamics of securitiesfraud actions, entire subsections of the IPO market remain insulated from any legal scrutiny.

Some may argue that smaller offering sized IPOs or IPOs with relatively small aftermarket losses are so minute in magnitude that reducing private enforcement for these IPOs will neither affect the overall level of investor confidence in the market nor noticeably increase the amount of fraud and misleading information in the market. Nevertheless, the smaller IPOs and IPOs with small aftermarket losses dominate in quantity. The majority of IPOs in our sample are under $\$ 5$ million in aftermarket losses; the majority of IPOs are also under $\$ 10$ million in offering amount. The majority of IPO suits, however, involve IPOs with greater than $\$ 5$ million in aftermarket losses and greater than $\$ 10$ million in offering amount. Most IPOs, therefore, receive relatively little private enforcement. This lack of private enforcement may tempt many smaller sized issuers to disclose misleading information. Furthermore, even larger issuers or issuers in unnoticed SIC code industries may seek to inflate the value of their offering slightly by an amount just small enough to discourage the attention of plaintiffs' attorneys. ${ }^{153}$

${ }^{152}$ It is possible that small aftermarket losses correlate with smaller amounts of misleading information disclosure. Therefore, the fact that companies with small aftermarket losses are not sued may not necessarily lead to the conclusion that more merit-based enforcement is needed against these companies. However, for companies with low capitalization, even a small aftermarket loss may translate into a large percentage drop in overall value. Therefore, the level of misleading disclosures for these companies may very well be large, yet the small size of the company translates this into only a small aftermarket loss. Furthermore, even for companies with high capitalization, controlling even small levels of misleading information may be important to protect investor confidence.

${ }^{153}$ Note that our sample is possibly biased against uncovering lawsuit IPOs with smaller dollar magnitude claims. See supra part II.A (describing the IPO data sample). To the extent that this bias problem is significant, our contention that private enforcement does not adequately police smaller sized offerings is weaker. Even for the smaller sized offering IPOs, however, the dollar magnitude of the potentially missing IPO lawsuits must be small enough to avoid disclosure within the firms' $10-\mathrm{K}$ 
This underenforcement phenomenon suggests a need for greater SEC enforcement. ${ }^{154}$ To the extent SEC enforcement efforts are more merit based than private actions, SEC enforcement should increase across the board. Moreover, even where private enforcement itself is merit-driven, the SEC should still intensify its enforcement for smaller sized IPOs, IPOs that experience only a moderate aftermarket loss, and IPOs in SIC code groups where plaintiffs' attorneys traditionally do not venture. This recommendation runs counter to the recent attempts in Congress to downsize the SEC. ${ }^{155}$

\section{EMPIRICAL TESTS OF THE ENFORCEMENT VERSUS THE STRIKE-SUIT THEORIES}

Unfortunately, determining whether a particular class action is merit or strike-suit based is not as easy as asking the plaintiffs' or defendants' attorneys on the case. Plaintiffs' attorneys will invariably argue that the defendants' fraudulent disclosure greatly harmed the interests of the investors. Defendants' attorneys, on the other hand, will contend that all disclosures were truthful and complete. ${ }^{156}$ Similarly, simply looking at the growth rate in securities litigation or the size of settlement awards does not answer the question of whether suits are meritorious or frivolous. The

and annual report disclosure statements. See supra note 106 (describing disclosure requirements for "material" litigation under Regulation S-K). Therefore, even for these smaller sized offering IPOs, the missing suits are relatively unimportant in terms of dollar magnitude.

${ }^{154}$ We do not necessarily argue for an expansion of private enforcement. Given the likelihood that a substantial portion of private litigation is frivolous, encouraging such litigation against small companies may result in a large amount of deterrence against even meritorious companies. Rather, we propose an expansion of SEC enforcement attention toward companies with smaller capitalization.

${ }^{155}$ For example, on September 7, 1995, the Senate Appropriations Commerce Subcommittee voted to reduce the funding of the SEC by $20 \%$. The Subcommittee also voted to phase out over a two-year period filing fees that the SEC uses to fund some of its activities. See SEC: Senate Appropriations Panel Votes to Slash SEC Funding By 20 Percent, BNA SEC. L. DAILY, Sept. 11, 1995, available in LEXIS, News Library, Curnws File.

${ }^{156}$ Even if plaintiffs' and defendants' attorneys were truthful, their adversarial role would still affect their opinions. See Alexander, supra note 12, at 506. Furthermore, collecting and analyzing the merits of every securities class-action IPO would take an enormous amount of effort and would turn, in part, on the researchers' subjective determination of the merits. See id. 
incidence of securities litigation or settlement awards may increase either because plaintiffs' attorneys are finding strike suits more profitable or because issuers are engaging in more fraud ex ante. Tests distinguishing between these two explanations would substantially illuminate this area of the law.

This Part presents five tests of the enforcement versus strike-suit theories of securities-fraud class actions. The first of these tests examines the plaintiffs' attorneys' decision to file suit and the factors that affect this decision. The quality of the IPO underwriter, in particular, drives the plaintiffs' attorneys' decision. The second test analyzes whether lawsuit IPO insiders sell off more of their shares during the IPO than nonlawsuit IPO insiders, using the amount of insiders' shares sold as a proxy for the ex ante merit of the offering. The results show that insiders do not sell more shares in a lawsuit IPO. For the third test, the preoffering corporate governance structure of the issuer serves as an alternative proxy for merit. The test examines whether weak, insider-dominated boardsboards which should display a greater amount of ex ante misbehavior-correlate with IPO-suit incidence. Lawsuit IPOs, in fact, do display more insider-dominated preoffering boards. The fourth test analyzes the factors affecting the settlement process in an IPO suit to determine whether settlement amounts depend on merit- or nonmerit-related factors. Settlement amounts seem to depend most on the potential damages award with little sensitivity to meritrelated factors. Finally, the fifth test consists of an event study of the returns and trading volume surrounding the public announcement of an IPO suit filing. This final test assesses whether price drop alone deterministically drives IPO suits. The event study demonstrates abnormal returns and elevated trading volume, indicating that publicly observable factors alone do not drive IPO suits. Information unknown to the public-including possibly meritrelated factors-must also drive the decision to file suit. Although the results of these five tests are mixed, on the whole they do provide strong evidence that at least a significant fraction of IPO suits are frivolous.

\section{A. The Decision to File Suit}

This Section explores the factors associated with a higher incidence of IPO shareholder litigation. As shown in Part II.A.3, the offering size of the IPO affects the incidence of shareholder 
litigation. Part II.A.4 highlighted that firms which experience larger aftermarket losses tend to be targeted for securities class-action suits. Part II.A.5 reported a wide variance in the incidence of shareholder litigation between firms in different industries. The results in Part II considered each factor in isolation. This Section analyzes the combined impact of these factors on the plaintiffs' attorneys' decision to file suit.

The factors examined include the quality of the underwriter, the offering amount, the offering price, the ratio of $R \& D$ and advertising expenditures to sales in the IPO's industry, and whether the IPO was conducted on a firm-commitment or best-efforts basis. The quality rating for a particular underwriter derives from Professors Carter and Manaster's study of underwriter quality in the IPO setting. ${ }^{157}$ Table 3.1 below uses a probit model to regress these factors against the dependent variable of whether the IPO firm experienced a securities-fraud class action. ${ }^{158}$

157 See Richard Carter \& Steven Manaster, Initial Public Offerings and Underwriter Reputation, 45 J. FIN. 1045, 1054-56 (1990). To construct a relative ranking of underwriter quality, Carter and Manaster examined the relative positioning of underwriters on tombstone announcements from January 1979 to December 1983. Outside of the managing underwriter, underwriters are placed in a series of different groups on the tombstone ads, increasing in distance from the top of the tombstone ads; within each group underwriters are listed alphabetically. Carter and Manaster ranked underwriters based on their relative group positioning. In cases where underwriter $A$ was higher than underwriter $B$ in one offering but was lower in another, they assigned $A$ and $B$ the same ranking.

${ }_{i 58}$ Testing for the significance of the individual SIC codes requires the addition of dummy variables for each SIC code in the probit model. Because almost 1000 possible three-digit SIC code dummy variables would be required to test industry significance of the three-digit SIC code level, such a test would lack statistical significance for our sample size. We therefore use R\&D/Sales and Ads/Sales as industry proxies rather than looking directly at SIC codes. 
TABLE 3.1: Predicting Class-Action Suits

\begin{tabular}{lcc}
\hline \hline & Model 1 & Model 2 \\
& & With Year Dummies \\
\hline INTERCEPT & $-6.839^{* * *}$ & $-7.742^{* * *}$ \\
& $(0.898)$ & $(1.060)$ \\
C-M RATING & $0.033^{*}$ & $0.032^{*}$ \\
OFFERPRI & $(0.022)$ & $(0.022)$ \\
& -0.447 & -0.903 \\
Log(AMOUNT) & $(0.609)$ & $(0.790)$ \\
& $0.292^{* * *}$ & $0.336^{* * *}$ \\
R\&D/SALES & $(0.059)$ & $(0.067)$ \\
& 1.588 & 0.841 \\
AD/SALES & $(1.789)$ & $(1.841)$ \\
& 0.319 & 0.313 \\
FIRMCOM & $(0.487)$ & $(0.487)$ \\
& 0.190 & 0.259 \\
Observations & $(0.188)$ & $(0.195)$ \\
\hline
\end{tabular}

Significant at the ${ }^{\circ} 20 \%$ level; ${ }^{\prime} 10 \%$ level; $\cdots 5$ level.

The probit model takes the dependent variable as one if the firm experienced a lawsuit and zero if the firm did not experience a lawsuit. C-M RATING is the mean Carter-Manaster rating of each IPO's underwriters. OFFERPRI is the offering price multiplied by 100 . Log(AMOUNT) is the natural log of the amount of money raised in the offering in 1993 dollars. R\&D/SALES and AD/SALES are respectively the industry ratios of $R \& D$ expenditures to sales and advertising expenditures to sales for the same three-digit industry as the IPO. FIRMCOM equals one if the offering was a firm-commitment or combined firm-commitment and best-efforts offering. Otherwise, FIRMCOM equals zero. A positive coefficient indicates that a rise in the independent variable increases the likelihood of experiencing a class-action suit. Standard errors are in parentheses.

Table 3.1 demonstrates that two factors have a statistically significant effect on the incidence of IPO securities class actions. First, the log of the offering amount is significant at the five-percent level. Consistent with the discussion in Part II, because plaintiffs' attorneys must recover their fixed costs of litigation, only the relatively larger offerings will be subject to securities class actions. Unlike in Part II, however, the proxies for industry type are not significant. $\mathrm{R} \& \mathrm{D}$ and advertising expenditures as a fraction of sales correlate positively with the incidence of suits, but not in a 
statistically significant manner. This is not necessarily incompatible with the theory that plaintiffs' attorneys must absorb a fixed cost to gain expertise in a particular industry. The test for $R \& D$ and advertising expenditures indicates that companies with relatively. high or fast-moving technologies and companies with a primarily consumer-products base ${ }^{159}$ tend-albeit weakly and without statistical significance-to experience more securities class actions. At any given level of R\&D or advertising expenditures, however, plaintiffs' attorneys may specialize only in certain SIC code industries. In other words, not all high-technology areas receive attention from securities plaintiffs' attorneys. Although the computer industry (SIC 737) certainly experiences a large proportion of fraud suits, other areas with high levels of R\&D/Sales lack similarly high incidences of litigation. For example, the drug manufacturing industry (SIC 283) also has a relatively high $\mathrm{R} \& \mathrm{D} /$ Sales ratio. Of the eighty-seven IPOs within the drug manufacturing SIC group, only one was the subject of a securities class action. ${ }^{160}$

Second, the underwriter quality of the IPO correlates with an increased presence of IPO suits. This result is statistically significant only at the twenty-percent level. Nevertheless, it provides strong evidence for the strike-suit theory because the enforcement theory predicts that underwriter quality should correlate, if at all, with a decreasing level of suit incidence. The higher the underwriter quality, typically, the higher is the quality of the IPO. ${ }^{161}$ Higher quality underwriters possess reputational capital based on their wellestablished merit. As a result, they draw more repeat investors attracted by the underwriters' reputation for delivering IPOs of relatively high quality and without potentially costly misleading information disclosure. Underwriters reap returns on this reputational capital through higher fees charged to issuers seeking access to the high quality underwriters' stable of repeat investors. These underwriters seek to maintain this reputational capital through careful screening of the potential issuers for misleading information disclosure and fraud. Therefore, higher quality underwriters should

${ }^{159}$ These companies spend considerably more on advertising than other companies.

${ }_{150}$ See supra part II.A.5 (reporting distribution of class actions by SIC code). We did not regress the SIC code of the IPOs directly because of the lack of continuity in the SIC code variable (for example, the SIC codes are discrete).

${ }^{161}$ See Ronald J. Gilson \& Reinier H. Kraakman, The Mechanisms of Market Efficiency, 70 VA. L. REV. 549, 620 (1984) ("In essence, the investment banker rents the issuer its reputation."). 
correlate with a lower incidence of ex ante fraud: the higher the quality of underwriters, the lower the incidence of ex post meritbased securities-fraud suits. ${ }^{162}$

Despite the reputational reasons for underwriters to screen issues for quality, underwriter quality may nevertheless not correlate with merit to the extent issuers attempting to mislead seek to associate with high quality underwriters. In essence, the high quality underwriters provide "cover" for the misleading issuers. Of course, underwriters seeking to maintain their reputation will attempt to stop these misleading issuers, but the underwriters may lack the capability to detect all types of fraud. Note, however, that at most this countereffect will result in no relationship between underwriter quality and merit. To the extent proportionally more misleading issuers associate with high quality underwriters, investors with rational expectations will realize this and penalize the associated issuers, eliminating the incentive of misleading issuers to go to high quality underwriters in the first place. The worst possible case, therefore, is a pooling equilibrium where the underwriter quality signals nothing about an offering's ex ante merit. In reality, underwriters have access to most company records and are able to screen for many types of fraud. In addition, truthful companies also gain more through association with high quality underwriters and will compete with misleading companies for the business of the high quality underwriters. Therefore, misleading issuers seeking to associate with high quality underwriters most likely reduce but do not eliminate the relationship between high quality underwriters and meritorious issues. ${ }^{163}$

${ }^{162}$ Indeed, several commentators have written on the possible incentive of underwriters to underprice an IPO. See supra note 36. The lower the offering price, the lower the chance that aftermarket trading will result in a price lower than the offer price. This in turn reduces the chances of a fraud suit against the offering. See Tiniç, supra note 36, at 800 (stating that underpricing of IPOs may protect against potential legal liabilities more efficiently than using due diligence). But see Alexander, supra note 36 , at 20 (concluding that "[t]he lawsuit avoidance theory thus is unlikely to account for more than a small part of the underpricing that has been observed"); Drake \& Vetsuypens, supra note 30 , at 64 (finding that underpricing IPOs "is not a very efficient way of avoiding future lawsuits").

${ }^{163}$ Alternatively, underwriter quality may correlate with fraud to the extent plaintiffs' attorneys base their search for fraud on extreme price changes. With underwriters of low quality, issues tend to be more volatile in their price movements; therefore, a large price drop may not communicate very much about the ex ante merits of the offering. For underwriters of high quality, however, issues are less volatile, making a large price drop more suspect and indicative of ex ante fraud. Even merit-based plaintiffs' attorneys, therefore, may target primarily high quality 
The fact that underwriter quality in fact correlates positively with suit incidence therefore suggests that suits are not always driven by merit-related factors. The positive nature of the relationship between underwriter quality and suit incidence favors instead the strike-suit theory. Higher quality underwriters are eager to protect their reputational capital from the damage associated with a securities-fraud suit. Because the underwriter's reputation rests primarily on its ability to deliver high quality issuers without misleading information disclosure or fraud, involvement in a securities-fraud class action is particularly harmful. ${ }^{164}$ Consequently, underwriters are eager to settle securities suits swiftly and without publicity. Plaintiffs' attorneys seeking to extort settlement money from any IPO which suffers a large enough aftermarket loss will realize this and actively sue the higher quality underwriters.

Table 3.2 provides an alternative test of the relationship between underwriter quality and suit incidence. In this alternative model, we took underwriter quality of the IPO as the dependent variable and regressed against the incidence of a suit, the offer price, the natural $\log$ of the offer quantity, the $R \& \mathrm{CD}$ and advertising to sales ratio of the IPO's industry, and the firm-commitment or best-efforts nature of the offer.

underwriters, leading to a positive correlation between underwriter quality and merit consistent with the enforcement theory. However, to the extent merit-based plaintiffs' attorneys have other sources of information on fraud besides the magnitude of the price drop, there is no necessary relationship between the incidence of suits and high quality underwriters.

16t Furthermore, the higher quality underwriters are probably more likely to carry higher coverage liability insurance. See Romano Letter, supra note 142, at 2. 
TABLE 3.2: Underwriter Choice and Underpricing of Lawsuit and Nonsuit Firms

\begin{tabular}{lcc}
\hline \hline & Model 1 & Model 2 \\
& Underwriter Rating & $\begin{array}{c}\text { Underwriter Rating with } \\
\text { Year Dummies }\end{array}$ \\
\hline INTERCEPT & $-24.813^{\cdots * *}$ & $-25.455^{* * *}$ \\
& $(0.511)$ & $(0.531)$ \\
SUIT & $0.306^{*}$ & $0.254^{*}$ \\
& $(0.193)$ & $(0.192)$ \\
OFFERPRI (x 100) & 0.025 & 0.021 \\
Log(AMOUNT) & $(0.022)$ & $(0.022)$ \\
R\&D/SALES & $1.701^{* * *}$ & $1.712^{* * *}$ \\
& $(0.034)$ & $(0.034)$ \\
AD/SALES & 1.815 & 0.410 \\
& $(1.523)$ & $(1.547)$ \\
FIRMCOM & -0.436 & -0.458 \\
Adj. R & $(0.569)$ & $(0.567)$ \\
\hline Observations & $1.246^{* * *}$ & $1.394^{* * *}$ \\
\hline
\end{tabular}

Significant at the ${ }^{\circ} 20 \%$ level; "* $10 \%$ level; "* $5 \%$ level.

In both Models 1 and 2, the dependent variable is the mean quality rating of the firm's underwriters based on Carter-Manaster's rating of underwriters. SUIT equals one if the firm experienced a class-action suit arising out of the initial offering, and zero otherwise. OFFERPRI is the offering price multiplied by 100. Log(AMOUNT) is the natural $\log$ of the amount of money raised in the offering in 1993 dollars. $\mathrm{R} \& \mathrm{D} / \mathrm{SALES}$ and $A D / S A L E S$ is the industry ratio of $R \& D$ expenditures to sales and advertising expenditures to sales for the same three-digit industry as the IPO. FIRMCOM equals one if the offering was a firm-commitment or combined firmcommitment/best-efforts offering, and zero otherwise. Standard errors are in parentheses. 
The results in Table 3.2 exhibit a strong, statistically significant relationship between the natural log of the offering amount and the underwriter quality of the IPO. Higher quality underwriters tend to associate with only the larger offerings. To the extent higher quality underwriters provide monitoring services for their investors, the cost of the services are more easily spread in larger offerings. Smaller offerings cannot justify the fixed monitoring costs of the higher quality underwriters. As with the results in Part II, this points to a lack of private market-based control of misleading information disclosure in smaller sized offerings. ${ }^{165}$

Like Table 3.1, Table 3.2 demonstrates a positive relationship between suit incidence and underwriter quality, weakly significant at the twenty-percent level. The results again provide some evidence that IPOs with underwriters of higher quality tend to experience a greater number of securities-fraud class-action suits and support the theory that plaintiffs' attorneys engage in strike suits, seeking to file suit against those underwriters most vulnerable to suits and most willing to settle quickly. At the very least, the positive relationship between suit incidence and underwriter quality bolsters the argument that greater levels of ex ante merit-related characteristics do not reduce the frequency of suits.

To test further the importance of underwriter quality in the decision to file suit, we matched the lawsuit IPOs against IPO firms that had similar levels of aftermarket losses but that did not experience a fraud class action. We calculated aftermarket losses as the number of shares issued at the time of the offering multiplied by the three-year low price of these shares in aftermarket trading. ${ }^{166}$ We based the three-year low on the University of Chicago Graduate School of Business's Center for Research in Securities Prices (CRSP) data on daily returns, adjusted for dividends and stock splits. We matched the lawsuit IPOs and IPO firms on the basis of total dollar losses to purchasers of the IPO and the percentage loss in value from the offering price. We selected the matching IPO firm within our IPO sample that had aftermarket losses most closely matched to those of the lawsuit IPO and losses calculated as a percentage of the

${ }^{165}$ Table 3.2 also indicates that higher quality underwriters tend to associate with firm-commitment over best-efforts offerings. This may be because higher quality underwriters are better capitalized and are therefore better able to purchase the issuers securities for resale under a firm-commitment offering.

${ }^{166}$ See supra part II.A.4 (discussing the weaknesses of this approach in calculating the aftermarket losses of shareholders). 
offering amount within ten percent of the lawsuit firm. Thirty-two firms had to be omitted due to missing data or because a suitable match was unavailable. The results appear below in Table 3.3.

TABLE 3.3: Firms Matched By Underperformance

\begin{tabular}{lccc}
\hline \hline & Lawsuit Firms & Matching Firms & p-value $^{*}$ \\
\hline $\begin{array}{l}\text { Mean Aftermarket } \\
\text { Loss (millions) }\end{array}$ & 17.075 & 16.532 & \\
$\begin{array}{l}\text { Loss in } \\
\text { Aftermarket }\end{array}$ & $74.29 \%$ & $74.66 \%$ & \\
Mean C-M Rating & 5.848 & & \\
$\begin{array}{l}\text { Mean Industry } \\
\text { R\&D/Sales }\end{array}$ & $2.34 \%$ & 5.159 & 0.077 \\
\hline Sample Size & 91 & $2.52 \%$ & 0.653 \\
\hline
\end{tabular}

* The p-value is the value of a two-sided test of the difference in mean values between the two samples.

The above data further supports two points. First, firms with more R\&D-high-technology firms-do not experience greater levels of securities class actions. High-technology in and of itself does not seem to explain the incidence of securities class actions. Although certain sectors of the high-technology area, most notably the computer SIC area, experience a disproportionate number of fraud suits, this trend does not generalize to all high-technology firms. Second, IPOs with higher quality underwriters tend to experience more fraud suits. ${ }^{167}$ Again, these results uphold the strike-suit theory of class actions because higher quality underwriters tend to associate with issuers with lower, not greater, levels of misleading information disclosure.

\section{B. Ex Ante Proxies for Merit}

To distinguish between the enforcement and strike-suit theories, this Section examines the IPO structure and the corporate governance of the issuers in the lawsuit sample. The enforcement theory implies that the incidence of lawsuit IPOs will correlate with the merit of the information disclosure during the offering. ${ }^{168}$ We use

${ }^{167}$ As Table 3.3 indicates, this is statistically significant at the $10 \%$ level.

${ }^{168}$ Naturally, IPO participants are able to observe ex ante proxies of merit at the 
two different proxies for ex ante merit. First, if insiders are purposefully issuing misleading statements in the prospectus, we expect that insiders in the lawsuit firms would sell a larger fraction of their total holdings and that insider sales would constitute a larger fraction of the total shares offered. Second, we also expect to see governance structures in the firms experiencing a shareholder lawsuit that are more conducive to opportunistic behavior on the part of insiders. ${ }^{169}$ On the other hand, the strike-suit theory points to no relation between these proxies for ex ante merit and securities class actions. In other words, there should be no necessary correlation between these indirect measures of ex ante merit and the occurrence of a frivolous securities-fraud suit. Regardless of merit, according to the strike-suit theory, opportunistic plaintiffs' attorneys sue all firms that experience enough of an aftermarket price decline. ${ }^{170}$

In order to control for variations in the likelihood of a lawsuit arising out of different types of initial public offerings, we partitioned the sample into those firms that were initially privately held and then went public, demutualizations, offerings of limited partnership shares, and spin-offs. ${ }^{171}$ The study focused solely on firms which were initially privately held. For each firm in the lawsuit sample, we chose a comparable firm that was also privately held prior to the offering and went public between 1975 and 1986. We selected the comparable firms by matching the firms' three-digit SIC codes and sales after adjusting for inflation. All comparable firms had sales between $25 \%$ and $400 \%$ of that of the matching lawsuit firm. If a suitable firm was unavailable in the same threedigit SIC category, we searched the adjacent three-digit industry categories until we could find a suitable match. In all cases, we inspected the business description of the prospectus summary to ensure that the lawsuit and matching firms were indeed in compara-

time of the IPO itself. To the extent these proxies indicate the possibility of fraud, potential purchasers of the securities will demand a lower offer price. Purchasers, therefore, will be compensated for the risk of fraud through the offer price. These purchasers still retain the right to initiate and pursue a securities-fraud claim. Because such a claim partially insures the purchasers against fraud, the offer price will not adjust as much. Furthermore, ex post, once fraud is revealed, these purchasers will use their securities-fraud cause of action against the IPO issuing team.

${ }^{169}$ Therefore, under the enforcement theory, the boards of directors of issuers that experience an IPO securities class action should contain relatively few outsiders. ${ }^{170}$ See supra part I.A (summarizing strike-suit theory).

171 We treat a spin-off as a firm in which another public corporation held $50 \%$ or more of the shares prior to the IPO. 
ble businesses. The final sample consisted of ninety-nine pairs, or 198 transactions. We used the matching firms to control for exogenous factors which might affect the relationship between suit incidence and our proxies for merit. ${ }^{172}$ The results of the matching process appear in Table 3.4.

TABLE 3.4: Construction of the Matching Sample

\begin{aligned} & \hline \hline 123 Total Lawsuit Firms \\ &-13 $\begin{array}{l}\text { Spin-Offs, Limited Partnerships \& } \\ \text { Demutualizations }\end{array} \\ &$\hline 110 Going Public Transactions \\ &-6 Prospectus Unavailable \\ &-5 No Suitable Match \\ & \hline 99 Matching Sample \\ & \hline\end{aligned}

1. Insider Sell-Off During the IPO

Insider sell-off during the IPO serves as the first proxy for ex ante merit. Insiders of a misleading issuer realize that the shares are overvalued and sell more to recover a windfall from this overvaluation. In a world where only the insiders of misleading issuers seek to sell greater numbers of shares, however, investors should be able to notice this ex ante and price down the IPO shares accordingly. As a result, insiders lose the incentive to sell greater numbers of shares and insider sell-off should not correlate with suit incidence or merit. Insiders, however, may sell greater numbers of shares for a variety of reasons; for example, some insiders sell for liquidity needs. Therefore, investors are not able ex ante to use insider sell-off to discriminate perfectly between misleading and truthful issuers. Insiders of misleading issuers, as a result, will attempt to sell a greater number of shares, leading to some positive correlation between insider sell-off and merit.

The insider sell-off proxy allows for a test of the dissimilarities in the structuring of the lawsuit IPOs and their nonlawsuit counter-

${ }^{172}$ For example, using matching pairs of firms controls for the possibility that the industry group that the lawsuit IPO firm belongs to actually drives the incidence of suits. 
parts. The insider sell-off proxy may be represented as either shares sold as a fraction of shares outstanding or insider shares as a fraction of shares sold in the IPO. The results of the matched pairs analysis of the offering structure of the lawsuit and control IPOs appear in Table 3.5 .

TABLE 3.5: Terms of the Transaction

\begin{tabular}{|c|c|c|c|}
\hline & Lawsuit & Control & p-value \\
\hline Sales in 1993 Dollars (thousands) & 63,225 & $\mathbf{5 7 , 3 5 7}$ & 0.643 \\
\hline $\begin{array}{l}\text { Size of Offering in } 1993 \text { Dollars } \\
\text { (thousands) }\end{array}$ & 35,149 & 24,734 & 0.039 \\
\hline $\begin{array}{l}\text { Ownership of Directors and } \\
\text { Officers Before Offering }\end{array}$ & $70.7 \%$ & $63.9 \%$ & 0.094 \\
\hline $\begin{array}{l}\text { Ownership of Directors and } \\
\text { Officers After Offering }\end{array}$ & $49.2 \%$ & $45.7 \%$ & 0.224 \\
\hline $\begin{array}{l}\text { Insider Shares as a Fraction of } \\
\text { Shares Outstanding Preoffering }\end{array}$ & $40.5 \%$ & $42.4 \%$ & 0.612 \\
\hline $\begin{array}{l}\text { Insider Sales as a Fraction of } \\
\text { Shares Sold }\end{array}$ & $27.9 \%$ & $25.8 \%$ & 0.841 \\
\hline Best-Efforts Offerings & 4 & 7 & \\
\hline Firm-Commitment Offerings & 95 & 92 & \\
\hline No Risk Factors Section & 50 & 45 & \\
\hline Separate Risk Factors Section & 49 & 54 & \\
\hline $\begin{array}{l}\text { Average Number of Risk Factors } \\
\text { Listed if Prospectus Contains a Risk } \\
\text { Factors Section }\end{array}$ & 9.375 & 10.519 & 0.464 \\
\hline $\begin{array}{l}\text { Average Underwriter Rating } \\
\text { (Carter-Manaster) }\end{array}$ & 5.615 & 4.642 & 0.017 \\
\hline
\end{tabular}

- The p-value is the value of a two-sided test of the difference in mean values between the two samples.

These results yield little support for the hypothesis that lawsuit IPO insiders are more likely to use new issues to mislead the public or bail themselves out of the issuing firm than nonlawsuit IPO insiders. Insiders do account for a larger fraction of the total shares sold in lawsuit IPOs than in the control nonlawsuit IPO group; however, the difference lacks statistical significance. Conversely, as a fraction of shares outstanding, lawsuit IPO insiders sold fewer 
shares than control IPO insiders. This result, however, is also not statistically significant. The only significant difference between the two groups is the size of the offering. ${ }^{178}$ The significantly larger size of the offerings of lawsuit IPOs is difficult to interpret. The larger size of the litigated offerings could be the product of inflation in the value of the shares due to the suppression of negative information in the offering prospectus. On the other hand, the larger size of lawsuit IPOs is consistent with the theory, as discussed above in Part II, that plaintiffs' attorneys focus their attention only on IPOs in which a suit has the potential to return an award for attorney's fees larger than the fixed costs of litigation. ${ }^{174}$

\section{Corporate Governance Structure}

The second proxy for ex ante merit is the structure of the preoffering board of directors. Under this proxy, the number of outside board members is taken to correlate with the level of misleading information disclosure in the offering. The lower the fraction of outsiders on issuer boards, the less vigorously we assume the board monitors firm behavior during the IPO. ${ }^{175}$ The fewer the outside board members, for example, the easier it is for insiders to defraud the public. This relationship in turn intimates that firms with a lower fraction of outside board members should have a higher incidence of securities fraud in their offerings. In Table 3.6, we compare the structures of the boards of directors of the two samples along a number of dimensions. ${ }^{176}$

${ }^{173}$ In their study of securities class actions, Francis, Philbrick, and Schipper found that lawsuit firms had statistically significant larger assets, sales, market share, number of employees, and shares outstanding than their industry-matched control firms. See Francis et al., supra note 32, at 11-12.

${ }^{174}$ An alternative hypothesis is that plaintiffs' attorneys do not select cases based on insiders' sales. See supra part II.B.2 (discussing plaintiffs' attorneys' incentives).

${ }^{175}$ Outsiders tend to monitor firm misbehavior more aggressively than insiders because outsiders have more reputation at stake and stand to gain less from the illicit gains of firm misbehavior. See, e.g., David L. White, Outside Directors Under the Federal Securities Laws: Fraudulent Actors or Innocent Victims?, 21 SEC. REG. L.J. 297, 299 (1993).

${ }^{176}$ The lawsuit IPO and matching IPO samples were not matched based on their IPO date. Because the number of outside directors has generally risen over the 1980 s, this may have biased our results. Most IPOs in our sample took place in the six years from the beginning of 1981 to the end of 1986 . Because most matching firms were also pulled from these six years, the level of bias, if any, should be minimal. 
TABLE 3.6: Governance of the Initial Public Offering

\begin{tabular}{lccc}
\hline \hline & Lawsuit & Control & p-value \\
\cline { 2 - 4 } & $49.4 \%$ & $44.6 \%$ & 0.109 \\
$\begin{array}{l}\text { Fraction of Seats Held By } \\
\text { Management }\end{array}$ & $9.8 \%$ & $10.7 \%$ & 0.739 \\
$\begin{array}{l}\text { Fraction of Seats Held By } \\
\text { Venture Capitalists }\end{array}$ & $3.7 \%$ & $3.1 \%$ & 0.548 \\
$\begin{array}{l}\text { Fraction of Seats Held By } \\
\text { Underwriters }\end{array}$ & $12.1 \%$ & $10.6 \%$ & 0.480 \\
$\begin{array}{l}\text { Fraction of Seats Held By } \\
\text { Other Agents }\end{array}$ & $24.8 \%$ & $30.9 \%$ & 0.031 \\
$\begin{array}{l}\text { Fraction of Seats Held By } \\
\text { Outsiders }\end{array}$ & 0.419 & 0.566 & 0.079 \\
$\begin{array}{l}\text { Average Number of Outside } \\
\text { Directorships Held }\end{array}$ & 6.05 & 6.59 & 0.080 \\
$\begin{array}{l}\text { Average Board Size } \\
\text { (Number of Seats) }\end{array}$ & & & \\
\hline
\end{tabular}

- The $\mathrm{p}$-value is the value of a two-sided test of the difference in mean values between the two samples.

"* Other agents include relatives of the management, founders of the firm who are not part of the management team, individuals who have a business relationship with the firm, and the firm's auditor or legal counsel.

-. Outsiders include all board members not associated with the management, venture capitalists, or underwriters. In our sample, outsiders typically were comprised of officers of unrelated corporations, professors, and other unrelated professionals.

The most striking result of the comparison between the two samples is the weakness of the board structure of the lawsuit firms relative to the control sample. Firms experiencing a lawsuit had a significantly lower fraction of outsiders on their boards of directors. Here, we defined outsiders to include all board members not associated with management, venture capitalists, or underwriters. Outsiders held only $24.8 \%$ of the board seats in lawsuit IPO issuers; conversely, outsiders held $30.9 \%$ of the board seats in the control IPO issuers. This difference was statistically significant at the fivepercent level. These results, therefore, provide support for the theory that lawsuit firms were sued for merit-related reasons.

The lower proportion of outsiders on the board of directors of an issuer that was eventually sued, however, does not necessarily indicate that lawsuit IPOs in fact had more fraud than nonlawsuit IPOs. First, the reduced presence of outsiders on the board may not lead to more issuer malfeasance if other substitute parties who 
have a reputational stake in the success of the firm-such as underwriters or venture capitalists-monitor the issuer instead. To test this, we decomposed the remainder of the board into various classes of directors. The results show that the lack of outside directors is largely due to the predominance of management representatives on the boards of directors ${ }^{177}$ and not due to an increased presence of either underwriters or venture capitalists. ${ }^{178}$ Table 3.6 shows that the proportion of venture capitalists on the board was in fact less for lawsuit IPOs than for the control IPOs. This statistic suggests that the monitoring role of the absent outside directors is not being filled by other substitute nonmanagement board members who have a reputational stake in the merits of the issue.

Second, lawsuit firms may also have more inside board members if they have ex ante nonmerit-related characteristics, which potential outside board members may use to distinguish lawsuit firms from other IPOs. ${ }^{179}$ For example, outside board members may avoid firms ex ante with particularly high levels of business risk-leaving only insiders to sit on the board..$^{180}$

To test whether differences in board composition are due to differences in the ex ante expected level of riskiness of the firm rather than merit-related characteristics, we regressed the fraction of outsiders on the board of directors against a dummy variable for whether the firm was involved in a shareholder suit and against control variables for the level of risk of the firm. Following Professors Beatty and Zajac's methodology ${ }^{181}$ we formed a measure of the expected volatility of the firm by regressing the actual standard deviation of returns for the first twenty trading days

${ }^{177}$ Management held $4.8 \%$ more board seats in lawsuit IPO firms than in nonlawsuit IPO firms.

${ }^{178}$ Arguably, underwriters and venture capitalists may also act as alternative monitors for fraud, thereby serving as proxies for ex ante merit. Underwriters and venture capitalists held $0.2 \%$ fewer board seats in lawsuit IPO firms than in nonlawsuit IPO firms.

${ }^{179}$ See Fletcher, supra note 22, at 501 (noting that "emerging growth companies, in the face of the continuous threat of nuisance suits, find it difficult to attract experienced outside directors since few directors dare risk damage to name and reputation from involvement in securities fraud litigation").

${ }^{180}$ Outsiders may wish to avoid firms with high levels of ex ante risk because firm failure may leave them personally vulnerable to shareholder suits. Firm failure may also reduce the personal reputation of outsiders.

${ }^{181}$ See Randolph P. Beatty \& Edward J. Zajac, Managerial Incentives, Monitoring, and Risk Bearing: A Study of Executive Compensation, Ownership, and Board Structure in Initial Public Offerings, 39 ADMIN. SCI. Q. 313, 321 (1994). 
(exclusive of the day of the offering) of firms that went public between 1975 and 1984 on a number of variables. The resulting measure of risk is the fitted value of the standard deviation for firms in our matched-pairs sample. ${ }^{182}$ In addition to the risks disclosed in the prospectus, smaller firms tend to pose more risk because they are not as well established in their markets. Therefore, the most recent 12-month preoffering sales in 1993 dollars are included in the list of controls for the riskiness of the firm. Results of board composition adjusted for total firm risk appear in Table 3.7.

TABLE 3.7: Board Composition Regression Results

\begin{tabular}{lcc}
\hline \hline & $\begin{array}{l}\text { Dependent Variable: } \\
\text { Fraction of Board Seats } \\
\text { Held By Outsiders }\end{array}$ & $\begin{array}{l}\text { Dependent Variable: } \\
\text { Average Number of Out- } \\
\text { side Board Seats Held }\end{array}$ \\
\cline { 2 - 3 } Constant & 0.2468 & 0.7775 \\
& $(0.0763)$ & $(0.2268)$ \\
Lawsuit Dummy & $-0.0584^{\circ *}$ & $-0.1549^{\circ}$ \\
Estimated Standard & $(0.0281)$ & $(0.0836)$ \\
Deviation & 1.1041 & -3.8305 \\
Sales in 1993 Dollars & $(1.242)$ & $(3.6944)$ \\
& $-9.7 \mathrm{e}-9$ & $1.4 \mathrm{e}-7$ \\
Adj. $\mathrm{R}^{2}$ & $(2.38 \mathrm{e}-7)$ & $(7.06 \mathrm{e}-7)$ \\
\end{tabular}

Significant at the ${ }^{\cdots *} 1 \%$ level; "“ $5 \%$ level; $10 \%$ level.

Even controlling for risk, the results indicate that the number of outside directors is lower for lawsuit firms. Where the dependent variable is the fraction of the board held by outsiders, for example, the presence of a lawsuit IPO lowers the outsider-controlled fraction by $\mathbf{5 . 8 4}$ percentage points. This result is statistically significant at the five-percent level. Risk alone, therefore, does not explain the

${ }^{182}$ The regression equation for the fitted values of the standard deviation $(\Sigma)$ of returns is:

$$
\begin{aligned}
\Sigma= & \text { constant }+b^{*}(\text { number of risk factors listed })+c^{*}(\text { dummy if no risk factors } \\
& \text { listed })+d^{*}(\text { firm-commitment dummy })+e
\end{aligned}
$$

The point estimates and standard errors for the constant were 0.0633 and 0.0291 , respectively; for the number of risk factors 0.001779 and 0.000158 ; for the no-riskfactors dummy 0.00715 and 0.002486 ; and for the firm-commitment dummy -0.02159 and 0.001955 . A daily standard deviation of returns of $3 \%$, for example, is measured as 0.03 in the regression. 
different proportions of outsiders on the boards of lawsuit versus nonlawsuit IPO issuers. ${ }^{183}$

Third, a greater number of outside directors does not necessarily translate into higher levels of monitoring and control over fraudulent statements if the quality of the outside directors is lower for lawsuit IPO firms. To test this proposition, we examined the quality of the directors serving on the boards of firms experiencing a lawsuit. We also examined the quality of directors on the board of a firm by taking the total number of board seats of other public companies held by members of the firm's board of directors and then dividing this number by the size of the firm's board. The results appear in Table 3.8 below.

TABLE 3.8: Quality of the Outside Directors on IPO Boards

\begin{tabular}{lccc}
\hline \hline & Lawsuit & Control & p-value $^{*}$ \\
\cline { 2 - 4 } & 0.419 & 0.566 & 0.079 \\
$\begin{array}{l}\text { Average Number of Outside } \\
\text { Directorships Held }\end{array}$ & 6.05 & 6.59 & 0.080 \\
$\begin{array}{l}\text { Average Board Size } \\
\text { (Number of Seats) }\end{array}$ & & & \\
\hline
\end{tabular}

- The p-value is the value of a two-sided test of the difference in mean values between the two samples.

Among lawsuit IPOs, the average number of outside directorships held was 0.419 . For the control IPOs, this number was 0.566 . This result is statistically significant at the ten-percent level. Lawsuit IPOs, therefore, tended to have lower, not higher, quality boards of directors. Because lawsuit IPOs correlate with this ex ante measure of merit, this result further supports the enforcement theory.

Finally, board composition may be unrelated to merit if firms with few outsiders on the board of directors are prone to succumb to rent-extracting efforts by plaintiffs. Insider-controlled boards may settle more frequently than outsider-dominated boards, for example, because outside board members prefer to develop "nosettle" reputations. Plaintiffs, however, most likely find it easier to extract rent from outsider-dominated boards. Board members are never part of the plaintiffs' class and therefore do not share in the

${ }^{183}$ Similarly, the result that the boards of lawsuit IPO issuers are of lower quality than nonlawsuit IPO issuers does not disappear when we control for the level of riskiness of the transactions in Table 3.7. 
distribution of the settlement amount. The settlement can be viewed as a special dividend from the corporate treasury to a select group of shareholders. Because outside directors typically hold a minimal stake in the firm, their personal wealth is not substantially affected by the amount of the settlement, and they, therefore, do not have a strong incentive to advocate a hard-bargaining stand for the firm in settlement negotiations.

Furthermore, especially in smaller firms, most outside directors do not expect to dedicate a large fraction of their time to board service. ${ }^{184}$ Outside directors may also have general business reputations that a public lawsuit would tarnish. ${ }^{185}$ Once a complaint is filed, therefore, outside board members are likely to advocate against trial or protracted negotiations. If merit were unrelated to the number of outside directors, one would expect that the firms with a higher fraction of outsiders would be more likely to experience litigation from rent-seeking plaintiffs' attorneys. Conversely, the fact that firms with a high fraction of outsiders experience less litigation provides support for the theory that merit does matter in securities class actions and that issuers with fewer outside directors act more opportunistically when bringing securities to the new-issues market. ${ }^{186}$

The outsider-director results, however, are only univariate, mean comparisons. To determine whether these results, the underwriter quality, and insider sell-off results above are robust, we calculated a probit model of the incidence of suits in Table 3.9. We estimated the probit model using the set of lawsuit IPOs and their matching IPO firms. ${ }^{187}$

${ }^{184}$ See, e.g., Ronald J. Gilson \& Reinier Kraakman, Reinventing the Outside Director: An Agenda for Institutional Investors, 43 STAN. L. REv. 863, 875 (1991) ("[O]utside directors lack the time, expertise, staff, and information to challenge management, while management controls not only these resources but also has a direct and powerful incentive to direct corporate policy without interference.").

${ }^{185}$ See Alexander, supra note 12, at 531-32 (noting that outside directors are unwilling to risk trial on the merits in securities litigation because of potentially large damages awards and possible damage to the directors' reputations).

${ }^{166}$ An alternative possibility is that plaintiffs' attorneys find it easier to win a merit-based action against IPOs with fewer numbers of outsiders because courts scrutinize the decisions of outsider-dominated boards less stringently than nonoutsider-dominated boards. However, neither section 11 nor Rule $10 \mathrm{~b}-5$ provides an exception for outsider-dominated boards. Furthermore, as demonstrated below, the result that IPO lawsuit firms have fewer outsiders on their boards loses statistical significance when underwriter quality and other factors are taken into account.

187 We do not estimate the probit model for the entire sample of IPOs because we lack data on the percentage of insider sell-off during the IPO and the board 
TABLE 3.9: Suit Incidence As a Function of Underwriter Quality and Board Composition

\begin{tabular}{lccc}
\hline \hline & Model 1 & Model 2 & Model 3 \\
& Suit Incidence & $\begin{array}{c}\text { Suit Incidence with } \\
\text { Offering Amount }\end{array}$ & $\begin{array}{c}\text { Suit Incidence with } \\
\text { Multiple Controls }\end{array}$ \\
\hline INTERCEPT & $-0.283^{*}$ & $-0.271^{*}$ & $-0.297^{*}$ \\
& $(0.196)$ & $(0.196)$ & $(0.197)$ \\
C-M RATING & $0.088^{* * * *}$ & $0.063^{* *}$ & $0.081^{* * *}$ \\
FRACOUT & $(0.033)$ & $(0.037)$ & $(0.035)$ \\
& -0.004 & 0.000 & -0.025 \\
OTHERDIR & $(0.120)$ & $(0.119)$ & $(0.121)$ \\
& $-0.343^{* * *}$ & $-0.389^{* * *}$ & $-0.341^{* * *}$ \\
AMOUNT & $(0.159)$ & $(0.163)$ & $(0.171)$ \\
(millions) & & $0.005^{* *}$ & \\
INSIDERSELL & & $(0.003)$ & 0.912 \\
& & & $(0.946)$ \\
VCBACK & & & -0.028 \\
\hline Observations & & & $(0.208)$ \\
\hline
\end{tabular}

Significant at the " $20 \%$ level; "* $10 \%$ level; "* $5 \%$ level; "** $1 \%$ level.

The probit model takes the dependent variable as one if the firm experienced a lawsuit and zero otherwise. The C-M RATING is the mean Carter-Manaster rating of each IPO's underwriters. FRACOUT is the fraction of outside directors on the board. OTHERDIR is the mean number of other directorships held by board members. AMOUNT is the offering amount of the IPO in millions of dollars. INSIDERSELL is the amount of insider sales during the offering as a percentage of the total offering size. VCBACK is a dummy variable of whether the IPO issuer had venture capital backers. A positive coefficient indicates that a rise in the independent variable increases the likelihood of experiencing a class-action suit. Standard errors appear in parentheses.

The first model in Table 3.9 assesses the interaction of underwriter quality, the fraction of outsiders on the issuer's board, and the level of insider sell-off during the IPO in explaining suit incidence. In combination, the fraction of board outsiders loses its statistical significance. Lawsuit IPOs do not have statistically

composition for every IPO in the sample. In addition, restricting the sample to IPO lawsuit firms and the matching firms controls for size and industry effects. 
significant fewer numbers of outside directors. The boards of lawsuit IPOs, however, do seem of lower quality as measured by the number of outsider directorships held by board members. Importantly, the result that higher underwriter quality does not translate into lower incidence of suit carries through at an extremely high level of statistical significance. In fact, as discussed above, higher underwriter quality appears to lead to even more suits, supporting the strike-suit theory.

We matched the matching firms in the sample, however, on the basis of SIC code and sales, and not on the basis of offering size. Therefore, it is possible that the statistically significant correlation between higher underwriter quality and suit incidence is actually driven by the larger size of the IPO lawsuit offerings. Larger offerings tend to attract higher quality underwriters; similarly, larger offerings are more likely to find themselves as targets of plaintiffs' suits. The large size of an offering provides a greater number of shares to spread the underwriters' commissions as well as larger potential damages awards for plaintiffs' attorneys. To control for offering size, therefore, the second model adds the offering amount as an independent variable. Although this reduces the statistical significance of the results from model one, the qualitative conclusions remain the same: underwriter quality correlates strongly with suit incidence while the percentage of outsiders on the board is statistically insignificant.

Finally, the third model in Table 3.9 tests two other control variables: the amount insiders sell as a fraction of the offering and a dummy variable for whether a venture capitalist is involved with the IPO firm. Similar to the univariate comparison of the mean insider sell-off between the lawsuit IPO and matching IPO samples, the probit results show that the relationship between insider sell-off and suit incidence is statistically insignificant. In addition, the presence of venture capitalists-an alternative proxy for ex ante merit-does not seem to decrease the incidence of suits. In fact, suit incidence increases with the presence of a venture capitalist, although this result is also statistically insignificant. Importantly, the result that higher underwriter quality leads to more suits is robust and remains significant in model three.

In summary, the preoffering board composition of the lawsuit and matching pair firms and aspects of the IPO transaction itself serve as proxies for the lawsuit merit-related aspects of the IPO. Firms with higher percentages of outsiders on the board of directors should experience greater outside monitoring and therefore have 
fewer instances of fraud or other illegal activities connected with the offering. The results demonstrate that lawsuit firms did, in fact, have boards with a lower fraction of outsiders than the nonlawsuit matching firms, providing support for the enforcement theory of securities class actions. A probit analysis of the relationship between the incidence of suits and board composition, underwriter quality, and insider sell-off during the IPO, however, demonstrates that in combination only underwriter quality remains statistically significant; suit incidence rises with underwriter quality, in support of the strike-suit theory.

\section{The Settlement Process}

This Section examines the settlement process in order to discriminate between the enforcement and strike-suit theories. Under the enforcement theory, the settlement amount should vary with merit-related factors and the expected damages award at trial. ${ }^{188}$ For example, as the expected damages award increases, the likely settlement award will also rise; plaintiffs' attorneys with large expected damages awards will not settle unless provided at least the amount they expect to receive from trial. ${ }^{189}$ The strikesuit theory, conversely, predicts that the settlement amount will not vary with merit-related factors. Under Rosenberg and Shavell, for example, strike suits receive the defendants' cost savings from avoiding the litigation, distraction, and reputation costs of responding to the plaintiffs' complaint. ${ }^{190}$ Similarly, in Bebchuk's model, strike suits receive an amount based on the saved litigation costs as well as the fraction of the population of suits which are NEV suits. ${ }^{191}$ In either case, the settlement amount for strike suits does not turn on the merits of the particular IPO. Alexander's particular form of the strike-suit theory, conversely, posits that settlement amounts, although not related to merits, should vary proportionally

${ }^{188}$ See supra notes 91-94 and accompanying text.

${ }^{189}$ Francis, Philbrick, and Schipper found that the settlement amounts of their sample of 91 securities lawsuits were relatively insensitive to the level of damages incurred; they did, however, find a statistically significant relationship between the log transformation of the settlement and damages amounts. See Francis et al., supra note 32, at 51-52. Their study provides a useful benchmark for our investigation into the relationship between settlement amounts and the level of potential damages, although Rule $10 \mathrm{~b}-5$ and section 11 have different requirements.

${ }^{190}$ See supra note 63 and accompanying text.

${ }^{191}$ See supra notes $66-67$ and accompanying text. 
with the maximum potential damages award. ${ }^{192}$ To test these different strike-suit theories against the enforcement theory, this Section analyzes whether merit impacts the settlement amounts. Under all the strike-suit theories, merit should not matter.

First, we regressed the settlement amount for each lawsuit IPO against the IPO's potential damages award. We calculated the potential damages award for each lawsuit IPO as the difference between the offer price and the price at the end of the class period multiplied by the number of shares issued. ${ }^{193}$ Although section 11 and Rule 10b-5 typically calculate the damages award based on the stock price at the time of the filing of suit, ${ }^{194}$ we used the price at the end of the class period to control for exogenous factors affecting the stock price between the end of the class period and the filing of suit. ${ }^{195}$ If the closing bid at the end of the class period was not available, we used the daily low trading price during the class period. We adjusted all damage and settlement amounts for inflation in 1993 dollars. ${ }^{196}$

Then, to determine whether merits affect the settlement amount, we also regressed the type of misleading statement alleged by the plaintiffs. Courts treat disclosures regarding objective information, such as inventory levels or revenues, differently from subjective "soft" information such as growth projections or discussions of the ability of management. In particular, courts tend to reject claims of misleading "soft" informational disclosures much more frequently as immaterial to a reasonable investor. ${ }^{197}$ Under

192 See Alexander, supra note 12, at 545.

193 The price at the end of the class period was obtained from the Daily Stock Price Record.

${ }^{194}$ See supra note 131 and accompanying text.

195 To the extent these exogenous factors are unrelated to the misleading information, defendants may reduce the potential damages award. See Securities Act § 11(e), 15 U.S.C. $\$ 77(e)$ (1994); see also supra notes $131-35$ and accompanying text (discussing problems with approximating the potential damages award). This measure is not perfect. It may overstate the potential damages award to the extent other exogenous factors affecting the stock price occurred prior to the end of the class period. It may also understate the potential damages award to the extent the market did not know of the issuer's misleading disclosure until the filing of suit.

${ }^{196}$ The potential damages award is adjusted to 1993 dollars from the end date of the class period. For settlements, the amounts are adjusted to 1993 dollars from the date a court first approves the settlement or the first public announcement of the settlement, whichever is earlier. If neither of these dates are available, the scttlement date is treated as four years after the IPO.

${ }^{197}$ See Searls v. Glasser, 64 F.3d 1061, 1067 (7th Cir. 1995) (noting that predictions of "high" disposition gains are "too vague . . . to affect the mix of more detailed information upon which a reasonable investor typically relies"); Hillson 
the enforcement theory, therefore, "soft" misleading information claims should result in lower merit-based expected damages. Meritbased settlement amounts, therefore, should reflect these lower expected damages. ${ }^{198}$

We examined press reports and court documents to determine the type of allegedly misleading statements or omissions in the offering prospectus or registration statement. Information on the source of the misleading information arose in eighty-seven of the 123 lawsuit IPO cases: in forty-two cases, the misleading information involved discussion of the business of the firm or of the ability of management, which include both predictive and subjective elements. In twenty-three cases, the source of the misleading information appeared within financial statements of the IPO, which most often dealt with objective, verifiable historical facts. Finally, twenty-two cases involved misleading statements dealing with both the financial statements and the business of the firm. Table 3.10 below presents the regression results.

Partners v. Adage, Inc., 42 F.3d 204, 220 (4th Cir. 1994) (noting that "imposing liability on companies for predictions of future growth, which are often . . . wrong, would lead to the further proliferation of lawsuits") (citing Raab v. General Physics Corp., 4 F.3d 286 (4th Cir. 1993)).

${ }^{198}$ Looking at the issuer's information disclosure policy during the offering may provide an alternative test of the merit versus strike-suit theories. Francis, Philbrick, and Schipper found that firms involved in shareholder lawsuits tend to have more active public disclosure than their nonlawsuit counterparts. See Francis et al., supra note 32 , at 49 . Two alternative hypotheses explain these results. First, lawsuit firms may tend to seek ex ante to mislead the public and therefore disclose more information to inflate the price of their shares. This corresponds to our definition of the enforcement theory because the enforcement theory hypothesizes a correlation between those firms which were sued and those firms which demonstrated ex ante misbehavior. Second, firms more prone to being sued may disclose more information in an attempt to protect themselves from liability.

In our sample, we found that IPOs involved in shareholder lawsuits are less likely to include a separate section on risk factors in their offering prospectus, and when they do, the IPOs tend to list fewer factors. In both cases, however, the difference is not statistically significant. This result is not necessarily inconsistent with the enforcement theory hypothesis because disclosure through risk factors may not lend itself as well to misleading the public as general informational disclosure. The results, on the other hand, do appear to contradict their theory that firms more prone to suit attempt to protect themselves ex ante through increased information disclosure. This may provide some indirect support for the strike-suit theory. Firms that realize ex ante that regardless of their actions, they will be sued if their stock price plummets will have no incentive to issue additional information ex ante. 
TABLE 3.10: Settlement Regression Results

Panel A: The sample consists of all IPOs with class periods less than one year in length for which the type of misleading information could be determined. The dependent variable is the settlement amount. The variable Damages refers to the potential damages award. We run an ordinary least squares regression (standard errors in parentheses) with $n=29$.

\begin{tabular}{lcc}
\hline \hline Constant & 169,098 & 721,670 \\
& $(668,069)$ & $(763,950)$ \\
Damages & $0.2115^{* * *}$ & $0.1863^{* * *}$ \\
& $(0.0219)$ & $(0.0330)$ \\
Damages x Accounting & & -0.01845 \\
& & $(0.1496)$ \\
Damages x Both & & 0.2118 \\
& & $(0.1531)$ \\
Adj. $\mathbf{R}^{2}$ & & 0.768 \\
F & 0.767 & 31.93 \\
\hline
\end{tabular}

F-test of difference in the fit of the regression: 1.0869

Significant at the "* $1 \%$ level; " $5 \%$ level; " $10 \%$ level.

Panel B: Same as Panel A excluding one outlier (Diasonics) and $\mathbf{n}=28$.

\begin{tabular}{lcc}
\hline \hline Constant & 542,911 & $1,002,703$ \\
& $(724,983)$ & $(800,187)$ \\
Damages & $0.1857^{* * *}$ & $0.1784^{\cdots \cdots}$ \\
& $(0.0299)$ & $(0.0336)$ \\
Damages x Accounting & & -0.2065 \\
& & $(0.1501)$ \\
Damages x Both & & 0.2008 \\
& & $(0.1527)$ \\
Adj. $\mathrm{R}^{2}$ & & 0.580 \\
$\mathrm{~F}$ & 0.582 & 13.44 \\
\hline
\end{tabular}

F-test of difference in the fit of the regression: 0.8984 .

Significant at the "*• $1 \%$ level; " $5 \%$ level; " $10 \%$ level. 
Panel C: The sample consists of all IPOs with identifiable class periods for which the type of misleading information is known. The dependent variable is settlement amount. Excluding one outlier (Crazy Eddie) and $\mathbf{n}=52$.

\begin{tabular}{lcc}
\hline \hline Constant & $\begin{array}{c}821,926 \\
(708,832)\end{array}$ & $\begin{array}{c}1,120,776^{*} \\
(618,020)\end{array}$ \\
Damages & $0.1405^{\cdots *}$ & $0.0805^{* \cdots}$ \\
& $(0.0232)$ & $(0.0241)$ \\
Damages x Accounting & & 0.0306 \\
& & $(0.0560)$ \\
Damages x Both & & $0.1071^{*}$ \\
& & $(0.0581)$ \\
Adj. $\mathrm{R}^{2}$ & 0.412 & 0.569 \\
F & 36.70 & 23.48 \\
\hline
\end{tabular}

F-test of difference in the fit of the regression: $10.11^{\cdots *}$

Significant at the "* $1 \%$ level; "* $5 \%$ level; ${ }^{*} 10 \%$ level.

In the first two panels of Table 3.10, we limited the sample to those firms with a class period of less than one year. For class actions with periods of less than one year, the calculation of the potential damages award measure is more likely to measure plaintiffs' maximum possible damages accurately, because within the first year, most defendants are still subject to the lockup agreements they entered into at the time of the IPO.$^{199}$ As the class period lengthens, the possibility that some aftermarket trading involves shares sold by members of the defendants' class (for example, insiders) increases. This may affect the potential damages award measure in a manner irrelevant to the plaintiffs' damages, ${ }^{200}$ increasing the

${ }^{199}$ Insiders in an IPO often enter into lockup agreements as part of the IPO whereby they promise not to sell their shares in secondary-market trading until a certain time period after the IPO. See Larry W. Sonsini, The Process of Going Public for First Time Issuers: An Overview, in CAPITAL FORMATION: PRIVATE AND PUBLIC FINANCINGS 1984, at 265, 276 (PLI Commercial Law \& Practice Course Handbook Series No. 335, 1984) (noting that the typical lockup agreement is between 90 and 180 days after the initial public offering). At least 36 of the lawsuit IPOs in our sample included a lockup agreement.

${ }^{200}$ The sale by insiders of shares in secondary-market trading may result in a greater number of shares outstanding than the number of shares sold in the IPO, resulting in an overestimate of the potential damages award. Similarly, to the extent purchasers of these post-IPO insider-sold shares are included in the scope of the lawsuit, the damage measure for these shares should be measured from the price at which the shares were sold by the insiders and not the IPO price. 
level of noise in the relationship between the potential damages award measure and the plaintiffs' damages.

The basic model for settlement amount appears in panel $\mathrm{A}$ of Table 3.10. The model indicates that the settlement amount is highly sensitive to the level of potential damages. For each dollar in additional potential damages, the settlement amount rises by twenty-one cents, a level similar to that reported by Alexander. ${ }^{201}$ These results, therefore, provide some support for Alexander's version of the strike-suit hypothesis. This support, however, is not unqualified: for merit-based suits, one would also expect to see settlement amounts rise with the level of potential damages. To test whether merit matters, the second model in panel A tests whether the sensitivity of the settlement amount to the potential damages award varies with the type of misleading information in the offering prospectus. The results of the second model again show that the settlement amount is highly sensitive to the potential damages award. Moreover, controlling for the type of misleading information in the prospectus has a negligible $(F=1.0869)$ effect on the fit of the model. Merit-related factors, therefore, do not significantly affect the relationship between the settlement amount and the potential damages award.

Panel B of Table 3.10 repeats the tests of Panel A, controlling for the effect of overly influential observations in the sample. One firm, Diasonics, had a potential damages award twice as large as any other firm in the sample. The removal of Diasonics from the sample, however, did not modify the basic conclusions. Only the potential damages award explains the settlement amount with any statistical significance. In all cases, the adjusted $R^{2}$ is over 0.50 , indicating that variation in damages accounts for over half of the variation in settlement amounts. Furthermore, the test whether merit-related factors affect the fit of the regression demonstrates a statistically insignificant difference between the fit of the two regressions $(F=0.8984)$.

Extending the regression model to include IPOs with longer class periods results in a diminished, but still statistically significant, relationship between the settlement amount and the potential damages award. These results appear in Panel $\mathrm{C}$ of Table 3.10. We exclude one outlier, Crazy Eddie, from our sample. ${ }^{202}$ The lower

${ }^{201}$ See Alexander, supra note 12, at 519 (finding an average settlement rate of $26 \%$ ).

${ }^{202}$ Crazy Eddic had the highest ratio of settlement award to potential damage 
value of the adjusted $R^{2}$ in cases with longer class periods indicates that the potential damages award explains less of the variation in settlement amounts as the class period increases. This is due in part to the effects of the passage of time and in part to the growing inaccuracy of the calculated measure for the potential damages award. Unlike in Panels A and B, however, the F-test statistic for the difference in fit between the two models in Panel $\mathrm{C}$ is statistically significant at the one-percent level. This could, however, be due to the higher degree of noise in the calculation of the potential damages award for longer class periods. Furthermore, the coefficients for the merit-related factors in Panel $\mathrm{C}$ are statistically insignificant.

In summary, the results of this Section provide evidence that settlement amounts track strongly with potential damages awards. However, the mere correlation between the settlement amount and the potential damages award is also consistent with the enforcement theory of class actions. To the extent that the potential damages award acts as a proxy for the harm resulting from fraud on the issuer's part, the potential damages award against the issuers that were actually sued should correlate with the amount of wrongdoing. It is unlikely, however, that merit correlates perfectly with the potential damages award. Two IPOs with identical potential damages awards of ten million dollars, for example, are unlikely to have exactly the same amount of ex ante fraud. Significantly, the regressions also demonstrate that the sensitivity of the settlement amount to the potential absolute damages award does not vary with the type of misleading information-indicating that merit does not matter. Therefore, that settlement amounts track consistently with the potential damages award provides some evidence for the strikesuit theory.

amount in the sample. There are a number of reasons to believe the case of Crazy Eddie is atypical. First, the firm had one of the longest class periods in the whole sample. Second, it was one of the few cases where the CEO, Eddie Antar, was also the subject of a related criminal case. Interestingly enough, plaintiffs' attorneys were praised in the Crazy Eddie litigation for their diligence and assistance to public enforcement efforts. See In re Crazy Eddie Sec. Litig., 824 F. Supp. 320, 323, 326-27 (E.D.N.Y. 1993). The results of the full sample (including Crazy Eddie), which are not reported here, are similar to those in Panel C. 


\section{Event Study of Returns at Time of Suit Filing}

The final test between the enforcement and strike-suit theories examines the reaction of the capital markets at the time a securitiesfraud suit is filed. Using the market model as a proxy for the returns generating process, we tested the existence of abnormal returns at the time a suit is filed using the event study methodologies outlined by Professors Brown and Warner. ${ }^{203}$ The market model provides a prediction of the returns the IPO lawsuit stocks should experience at any point in time based on an estimated relationship between the IPO stocks' returns and the returns of a value-weighed portfolio of all market stocks. ${ }^{204}$ Abnormal returns differing from the market model predicted returns indicate new, unanticipated information on the value of the IPO lawsuit firm. Furthermore, the sign of the abnormal returns provides evidence on whether the market considers the new information as positively or negatively impacting the value of the IPO lawsuit firm.

Because the filing of a securities-fraud class action is a relatively rare event, ${ }^{205}$ we predict that the filing of suit provides new information to the market regardless of whether it is merit or strikesuit based. The sign of the abnormal returns, however, may differ. Both merit and strike-suit motivated actions will reduce shareholder value to the extent that the defendant-issuer must expend resources in litigation. Furthermore, those purchasing the IPO stock on the date the suit is filed are not typically included in the class period. ${ }^{206}$ Therefore, any judgment or settlement paid for either a merit or strike-suit motivated action will reduce the value of shares traded after the filing of suit. Both merit and strike-suit actions should experience negative abnormal returns. Merit suits, however, may result in changes in the issuer's board of directors or executive compensation structure or may attract the attention of potential outside bidders for the company, all potentially raising shareholder value. To the extent these effects outweigh the

${ }^{203}$ See generally Stephen J. Brown \& Jerold B. Warner, Using Daily Stock Returns: The Case of Event Studies, 14 J. FIN. ECON. 3 (1985) (describing the methodology of using risk-adjusting returns in event studies).

${ }_{204}$ This relationship is based on historical data on the covariance of a particular IPO stock's returns and the value-weighed market portfolio returns.

${ }^{205}$ See supra part I.A.

${ }^{206}$ Purchasers buying after the filing of suit cannot claim that they relied on misleading information at the time of the IPO because the filing of suit signals to the market the misleading information. 
value. To the extent these effects outweigh the negative impact of a suit, merit-based suits may generate abnormal positive returns.

The results presented in Table 3.11 indicate that firms that were targets of a shareholder suit experienced negative abnormal returns in the three-day window centered on the filing date of the suit. This indicates that the market did not fully anticipate the decision of the plaintiffs' attorney to file a complaint. We analyzed trading volume around the filing of suit date to determine whether the information signaled by the filing affects investor expectations. ${ }^{207}$ A large increase in trading volume indicates that individual investor expectations have changed and that there is greater dispersion among investors regarding the value of the firm. The results in Table 3.11 again show a statistically significant increase in trading volume on the event date and in the three-day window around the event date, indicating that the filing of suit caused investors to revise their individual expectations regarding the value of the firm. Clearly, the market failed to fully anticipate these suits.

TABLE 3.11: Market Reaction to the Filing Announcement ( $t$-value in parenthesis)

\begin{tabular}{lcc}
\hline \hline Event Window & $\begin{array}{c}\text { Average Abnormal } \\
\text { Return }\end{array}$ & $\begin{array}{c}\text { Abnormal Trading } \\
\text { Volume As a Fraction } \\
\text { of Total Float }\end{array}$ \\
\hline Day 0 & $\begin{array}{c}-1.30 \%^{*} \\
(-1.76)\end{array}$ & $\begin{array}{c}0.001903^{* *} \\
(2.56)\end{array}$ \\
Day -1 to Day +1 & $-3.33 \%^{\cdots *}$ & $0.006642^{\cdots *}$ \\
& $(-2.605)$ & $(5.18)$ \\
\hline
\end{tabular}

Significant at the ${ }^{\cdots *} 1 \%$ level; ${ }^{\cdots} 5 \%$ level; ${ }^{\bullet} 10 \%$ level.

More significantly, the results in Table 3.11 fail to rule out strike suits. During the one-day event window centered on the suit filing date, the average abnormal return for suits was $-1.30 \%$; this was significant at the ten-percent level. The return around the three-day window was $-3.33 \%$ at the one-percent level. As discussed above, a negative return is consistent with both the merit and strike-suit theories. Although these results do not conclusively rule out merit-

${ }^{207}$ For a theory to test price reaction to earning announcements, see William $\mathrm{H}$. Beaver, The Information Content of Annual Earnings Announcements, 6 J. AccT. RESEARCH 67 (Supp. 1968). 
based suits, given the findings of the other tests in this Article, they do provide more evidence for the general hypothesis that many securities-fraud class actions are frivolous.

\section{CONCLUSION}

Justice Brandeis once wrote, "Sunlight is said to be the best of disinfectants; electric light the most efficient policeman." 208 To provide an incentive for issuers in the new-issues market to disclose information truthfully, the law gives IPO investors a variety of remedies in case of fraud or violations of the rigid procedural requirements imposed on new securities issuers. ${ }^{209}$ Some commentators, however, have argued that such remedies fail to enforce the securities laws; rather, they act as a form of inefficient insurance for IPO stock value. ${ }^{210}$ According to this story, armies of plaintiffs' attorneys sit on the sidelines-or more realistically in front of their computer terminals-waiting for the stock price of an IPO in aftermarket trading to drop. Faced with such a suit, issuers and their underwriting team will invariably settle due to risk aversion, liability insurance for outside directors and officers, and the negative impact that litigation will have on future business. ${ }^{211}$

To counter the strike-suit theory of securities class actions, other commentators have argued that the remedies provided by the securities laws do, in fact, ensure that issuers ex ante take care to divulge information necessary for investors to make their investment decisions. ${ }^{212}$ According to the enforcement theory, plaintiffs' attorneys-by facilitating this process-serve a valuable purpose. Without such attorneys, enforcement of the securities laws would be left solely to the SEC. However, because the SEC lacks information about which issuers are acting fraudulently and lacks the resources to pursue all such issuers, SEC enforcement is far from ideal.

This Article's empirical results show that most securities-fraud class actions are, in fact, frivolous. The evidence indicates that suits tend to correlate with higher quality underwriters. To the extent higher quality underwriters associate with higher quality offerings, this correlation demonstrates that something other than merit drives

${ }^{208}$ Louis D. BRANDEIS, OTher PeOPle's MONEY: AND How THE BANKers USE IT 92 (1914).

${ }^{209}$ See supra notes $41-47$ and accompanying text.

${ }^{210}$ See Alexander, supra note 12 , at 570-73.

211 See id.

212 See Lerach, supra note 18 , at 55-76. 
plaintiffs' attorneys. Moreover, the amount insiders sell of their own holdings during an IPO is not statistically different between lawsuit and nonlawsuit IPOs. Because insiders will choose to inflate the price of their IPO when they have the most to gain from a higher IPO price, insider sell-off is taken as an ex ante measure of the IPO's merit. The lack of any statistically significant difference, therefore, also supports the theory that something other than merit motivates plaintiffs' attorneys. Finally, once a suit is filed against an issuing team, almost all of them end in settlement with the absolute level of damages accounting for a large fraction of the variation in settlement amount between cases. ${ }^{213}$ Furthermore, merit-related factors do not affect this relationship.

On the other hand, evidence exists pointing to at least some merit-based enforcement actions. IPO issuers with fewer outsiders on their board of directors experience a higher incidence of class actions. The boards of IPOs which experience securities fraud-class actions are also of inferior quality than nonlawsuit IPOs. To the extent board composition is a proxy for the presence of ex ante opportunistic behavior on the issuer's part, these results suggest that the merits do matter-at least with respect to the plaintiffs' attorneys' initial decision whether or not to file suit. A probit analysis of the relationship between the incidence of suits and board composition, underwriter quality, and insider sell-off during the IPO, however, demonstrates that only underwriter quality remains statistically significant; suit incidence rises with underwriter quality, in support of the strike-suit theory.

Surely, at least some securities-fraud suits are merit based. The presence of these merit-based suits provides deterrence against ex ante fraud. Even if, for example, the ex post incidence of meritbased IPO suits is, in fact, only one out of every ten suits, this one suit may, in turn, deter many times its number of fraudulent IPOs. ${ }^{214}$ Nevertheless, the strong evidence that most suits are frivolous should lead lawmakers to reconsider the desirability of allowing securities-fraud class actions directed at IPOs. Although IPO securities class actions were small in number, the average settlement amount per suit was $\$ 5.3$ million in 1993 dollars. IPOs).

${ }^{219}$ See supra part II.A.2 (reporting the resolution and disposition of the lawsuit

${ }^{214}$ It is, however, unclear how to quantify the amount of "phantom" fraud which ex post merit-based suits actually deters ex ante. Romano makes a similar point in her study. See Romano, supra note 29 , at 85. 
Because the incidence of suits was $3.5 \%$ and the settlement rate was $75.6 \%$, all IPOs in our sample ex ante faced an expected litigation liability of $\$ 145,000$ in 1993 dollars. To the extent all suits are in fact frivolous, this expected liability functions as a tax on IPOs. ${ }^{215}$ Furthermore, this may understate the actual expected litigation liability that firms in certain SIC groupings face. Particular industries in our IPO sample encountered a far greater proportion of securities-fraud class actions. IPO securities litigation, for example, placed a much greater burden on computer IPOs. To reduce this tax on capital formation while maintaining deterrence of misleading information, lawmakers should consider greater public enforcement or alternative means of enabling private market mechanisms to self-police against fraud in the market. ${ }^{216}$

The results also indicate quite strongly that the incentives of plaintiffs' attorneys drive IPO securities class actions. As mentioned above, suits cluster in certain SIC groupings and rise in frequency as both the offering amount and aftermarket losses of an IPO increase. ${ }^{217}$ Plaintiffs' attorneys face several fixed costs of litigation regardless of the potential damages award. They must, for instance, conduct depositions, file motions, and learn about the particular circumstances of the issuer and its industry. Unless the expected fee-often a function of the potential damages awardexceeds this fixed cost, plaintiffs' attorneys will not file suit regardless of either the merits or strike-suit motivations. Similarly, plaintiffs' attorneys incur a cost to gain knowledge on a particular industry. This fixed cost results in plaintiffs' attorneys focusing only on certain industry groups.

Our findings on the incentives of plaintiffs' attorneys indicate that enforcement-to the extent it exists-occurs only for larger sized IPOs in certain industry groups. Private enforcement, therefore, leaves a large gap among smaller sized IPOs and IPOs in less frequently litigated SIC groups. In response, the SEC should focus its public enforcement efforts on areas lacking aggressive private enforcement.

${ }^{215}$ Because the average offering amount was $\$ 16.6$ million in 1993 dollars, this represented a tax of $1.1 \%$ on all IPOs.

${ }^{216}$ See, e.g., Stephen Choi, Misleading Information in the New Issues Markets: The Interdependence of Antifraud Mechanisms (Feb. 12, 1996) (unpublished manuscript on file with author) (analyzing the relationship between legal liability and marketbased mechanisms to control misleading information in the securities markets).

${ }^{217}$ See supra part II.A.3-4 (reporting the distribution of IPOs and lawsuits by IPO offering amount and aftermarket losses). 
Only further research will sufficiently illuminate the incentives of plaintiffs' attorneys and the other drivers behind securities-fraud class actions. While our effort focused on the initial public offerings market, to the extent other securities markets are similar to this market, our findings apply to securities-fraud suits in these other markets as well. 